Federal Reserve Bank of Minneapolis

Research Department

\title{
Inflation and Financial Market Performance
}

John H. Boyd, Ross Levine, and Bruce D. Smith*

Working Paper 573D

Revised July 1997

*Boyd, Federal Reserve Bank of Minneapolis and University of Minnesota; Levine, The World Bank; Smith, Federal Reserve Bank of Minneapolis and University of Texas-Austin. We would like to thank Michelle Barnes for outstanding research assistance and seminar participants at the Financial Markets Group, London School of Economics, the National Institute for Economic and Social Research, and the Federal Reserve Banks of Atlanta and Cleveland (especially Chris Sims and Finn Kydland) for their comments. The views expressed herein are those of the authors and not necessarily those of the Federal Reserve Bank of Minneapolis or the Federal Reserve System. 
Many researchers, employing many different methodologies, have documented an extremely strong positive correlation between measures of financial market development and real economic performance. On average, countries with well-developed financial systems have higher levels of real activity, and more rapid rates of real growth, other things being equal, than do economies with more primitive financial markets. Both measures of the development of the banking system, and the development of equity markets display this strong positive correlation with real sector performance. ${ }^{1}$

At the same time, many studies suggest the existence of a significantly negative correlation between inflation and an economy's real economic performance. Moveover, much of the relevant literature indicates that the negative correlation between inflation and growth performance derives largely from the experiences of relatively high inflation economies, ${ }^{2}$ and hence that the relationship between inflation and real activity is nonlinear. Indeed, Bullard and Keating (1995) find that incremental increases in inflation have substantially different long-run effects in economies with low versus high initial rates of inflation, while Bruno and Easterly (1995) find strong evidence of threshold effects associated with the rate of inflation exceeding some critical level. However, the mechanism underlying this apparently nonlinear association remains to be unearthed.

In this paper we investigate the empirical association between inflation and several indicators of an economy's financial market performance. We find substantial evidence that inflation is negatively correlated with financial market performance and, in addition, that the relationship between inflation and financial development exhibits substantial nonlinearities. In particular, economies with high rates of inflation have significantly less well-developed financial systems than economies with lower inflation rates. Therefore, given the strong correlation between financial market development and economic growth, our results are quite consistent with the kinds of correlations found between inflation and long-run real performance. 
Perhaps surprisingly, we appear to be among the first to investigate the nature of the empirical relationship between inflation and financial market performance. While Aiyagari, Braun, and Eckstein (1996) and English (1996) show that high rates of inflation induce agents to economize on money balances-and induce the financial system to provide more efficient transactions services-this finding touches on only a small subset of the services performed by the financial sector. In fact, banks and equity markets also mobilize savings and allocate investment capital. How these activities are affected by inflation is a topic of at least equal importance. Similarly, while various authors have investigated the time-series relationship between inflation and equity market returns (e.g., Amihud 1996; Boudoukh and Richardson 1993; Breen, Glosten, and Jagannathan 1989; Erb, Harvey, and Viskanta 1995; Jovanovic and Ueda 1996), they have not investigated the interactions between inflation and the size or liquidity of the financial system. The lack of evidence regarding the relationship between inflation and financial market performance seems a significant omission, particularly in light of the fact that financial market variables are strong predictors of long-run growth (King and Levine 1993b,c). We therefore attempt to document the nature of the empirical linkages between inflation and those measures of financial market development that have been found to be strongly correlated with economic growth.

In order to do so, we employ time-averaged data over periods of several decades from a large number of countries, and explore the cross-sectional relationship between inflation and an array of financial market indicators. By examining time-averaged data over long periods, we hope to isolate long-run correlations between inflation and financial market conditions, and to minimize the influence of cyclical factors. Thus, our results are informative on the relationship between sustained inflations and the long-term development of financial systems. This is presumably what may be relevant for long-run growth. 
We find several statistically significant and economically meaningful relationships between inflation and various measures of financial market performance. First, at moderate rates of inflation, there is a strong negative association between inflation and (a) measures of financial sector lending to the private sector, (b) the quantity of bank liabilities issued, and (c) measures of stock market liquidity and trading volume. Second, the empirical relationship between inflation and financial market performance is highly nonlinear. As inflation increases, the relationship between inflation and both banking and equity market activity "flattens-out;" indeed, at higher inflation rates further increases in inflation are associated with smaller and smaller declines in financial market activity. Third, we find that at moderate rates of inflation, marginal increases in predictable inflation are not matched by increases in nominal equity returns. This result confirms several earlier findings using time series data from individual countries. ${ }^{3}$ However, in economies where inflation rates are sufficiently high, nominal stock returns move essentially one-for-one with further increases in the rate of inflation. Even so, on average nominal equity returns decline discretely by a significant amount when the average rate of inflation exceeds 15 percent. Finally, both stock return volatility and some measures of international capital market segmentation are positively correlated with the rate of inflation. None of these findings are sensitive to alternative specifications (except as noted), the choice of sample period, or to the exclusion of high-inflation countries, or OPEC countries, from the sample.

Our analysis makes no attempt to attribute causation, yet it is interesting to think about what kinds of theoretical models are consistent with our findings. We are aware of three general classes of models that can confront our observations, although there may be others. In one class of models, the operation of the financial system affects the allocation of savings and investment in the presence of various informational asymmetries. In these models, high rates of inflation exacerbate financial market frictions, interfere with the efficiency of the financial system, and thus inhibit long-run growth. 
Moreover, such models easily generate development traps and threshold effects. In particular, there may exist multiple steady states; some with high and some with low levels of real activity. In the high (low) activity steady state, the financial market frictions confronting the economy are relatively mild (severe). Moreover, at low rates of inflation both steady states can be approached. However, high rates of inflation render the high activity steady state unstable. There are therefore critical rates of inflation in these models; when inflation exceeds these thresholds, the high activity steady state cannot be approached, and financial market frictions will be relatively severe. Finally, these models typically predict that high rates of inflation can induce endogenously arising volatility in all variables, including equity returns, and that high rates of inflation are associated with low real returns to saving.

A second class of models that might "explain" our findings focuses on the behavior of governments confronted with the necessity of financing a deficit. Governments with large seigniorage revenue needs may-for optimal taxation reasons-take actions to increase their inflation tax bases. Thus governments with large deficits are forced to rely heavily on inflationary taxation, and they also will tend to take actions to "repress" their financial systems. This would "explain" a negative correlation between inflation and the level of activity in financial markets. ${ }^{5}$ Moreover, some such models predict that the government should only intervene in financial markets when deficits (and inflation) exceed a critical level (Bencivenga and Smith 1992). They therefore potentially predict threshold effects.

A third potential explanation of our results is that financial development is a normal good. Economic growth naturally engenders a more developed financial system. At the same time, higher real growth rates imply lower rates of inflation, other things equal. Hence, inflation and financial market performance may be correlated only because economic growth, whose source may be sought elsewhere, affects both. 
Based on these alternative theoretical explanations (which are not necessarily mutually exclusive), we investigate the nature of the correlation between inflation and financial market performance while controlling for the state of fiscal policy and for conventional determinants of real rates of growth. We find that the correlation patterns noted above remain basically unchanged after controlling for other growth determinants and for fiscal conditions that might intensify government interference in the financial system. Such findings tentatively suggest that the finance-inflation relationship is driven neither by fiscal considerations, nor by a passive response of both variables to economic growth.

It should be noted that the results of our investigation have potentially important implications for the conduct of policy. For example, the World Bank's Operating Directive on financial sector activities takes the view that high rates of inflation are intrinsically detrimental to the functioning of financial systems. As a result, it advocates that many more fundamental financial sector reforms should not be undertaken in developing economies until their inflation rates are sufficiently low. Our findings seem supportive of the notion that it is difficult to stimulate financial market development in the face of an excessively large, sustained inflation (where excessively large may mean rates of inflation as low as 15 percent). Thus our results could be taken as empirical support for the necessity of "getting inflation under control."

Finally, we note that while our analysis clearly shows that the inflation-financial performance relationship is nonlinear, the analysis does not establish the precise nature of this nonlinearity. Specifically, the analysis does not imply that the relationship is necessarily characterized by a unique break or threshold. We find significant changes in the inflation-financial development relationship at a wide range of threshold inflation rates. Further, we find that the inflation-financial development relationship changes relatively smoothly as one moves from lower to higher inflation thresholds. Moreover, we examine a very wide array of financial market and financial intermediary development 
indicators, so that the precise nature of the nonlinearity is likely to vary across these different indicators. Thus, in this initial effort to characterize the empirical relationship between inflation and financial sector performance, we focus on making the more general-and robust-point that the strong negative relationship between inflation and financial performance becomes less pronounced at higher inflation rates.

The remainder of the paper proceeds as follows. Section I describes the data set employed, and does a preliminary investigation of simple correlations between inflation and financial market performance measures. Section II undertakes a more formal analysis of these correlations, controlling for a number of factors that might affect both the rate of inflation, and the development of the financial system. Both banking activity and equity markets are analyzed. Section III offers some concluding remarks.

\section{Data and Summary Statistics}

To investigate the relationship between inflation and financial development, we use two data sets describing banking and stock market activity.

\section{A. Banking Data Set: 1960-1989}

\section{Data Description}

The first data set focuses on measures of banking development. It covers the period 1960-89, includes data on 119 countries (data permitting), and is taken from King and Levine (1993a,b). For short, we call this the "banking data set," and it includes five financial development measures. ${ }^{6}$

$M 1 Y$ equals the ratio of a country's currency (held outside of the banking system) plus demand deposits to its Gross Domestic Product $(G D P) .^{7}$ This gauges the scale of domestic currency funds held by individuals and corporations principally for transactions. $M 1 Y$ may not capture broader aspects of financial development since it is based on a relatively narrow measure of money. And 
indeed, $M 1 Y$ is not particularly strongly correlated with some other measures of bank activity, as is apparent from Table 1. In addition, as noted by King and Levine (1993c), $M 1 Y$ is not very strongly associated with the level of economic development, but $M 1 Y$ is positively correlated with economic growth over the 1960-89 period.

$L L Y$ equals the ratio of liquid liabilities of the financial system to $G D P$, where liquid liabilities are defined as $M 1$ plus interest bearing liabilities of the banking system, plus demand and interest bearing liabilities of other financial intermediaries (savings banks, postal savings institutions, finance companies, etc. $)^{8}$ This indicator measures the overall size of the formal financial intermediary sector and is very strongly associated with both the level and rate of change of real per capita GDP over this sample period (King and Levine 1993c).

$Q L L Y$ equals $L L Y$ minus $M 1 Y$ and is frequently called, "quasi-liquid liabilities." $Q L L Y$ eliminates the purely monetary component of financial system size to create a measure of nonmonetary financial sector depth. $Q L L Y$ is also positively correlated with both the level of economic development and the growth rate of real per capita GDP over this sample period (King and Levine 1993c).

$P R I V Y$ equals the ratio of claims on the private sector held by the financial sector to $G D P$. This is both a measure of the size of the financial sector and an indicator of asset distribution since it excludes credits to the government and publicly owned enterprises. ${ }^{9}$ The presumption underlying the use of this measure is that greater financial sector development is positively correlated with credit extension to private firms as opposed to the government. This measure of financial development is positively associated with the level and growth rate of real per capita GDP (King and Levine 1993c).

$B A N K$ equals the ratio of deposit money bank domestic assets to deposit money bank plus central bank domestic assets. BANK measures the importance of deposit money banks (commercial banks and other deposit taking banks) relative to the central bank in issuing credits. ${ }^{10}$ The notion 
underlying this measure is that greater financial sector development is positively correlated with banks playing a larger role relative to the central bank in allocating credit. BANK is also positively correlated with economic development (King and Levine 1993c).

To measure inflation $(P I)$, we compute the average annual rate of growth of the GDP deflator, which is taken from the World Bank National Accounts data base. STPI is the standard deviation of inflation (STPI), which is very highly correlated with $P I(0.97)$.

\section{Correlations and Quartile Statistics}

Table 1 presents correlations over the period 1960-89 between the various financial development indicators, inflation, and the standard deviation of inflation for the complete sample of countries excluding major oil exporting countries. ${ }^{11}$ All of the financial development indicators are negatively correlated with inflation, although none is significantly correlated at the 0.05 significance level. However, as we will show, these simple correlations do not tell the whole story. It is also worth noting that the financial market variables are all positively correlated, as one would expect. However, they are far from perfectly correlated, suggesting that they capture different dimensions of financial market performance.

Table 2 presents means and medians after the data have been sorted by inflation and broken into quartiles. Two points are worth highlighting. First, the average (or median) inflation rate in the highest inflation quartile dramatically exceeds that in the rest of the sample. In particular, the average (median) inflation rate in the first quartile was 4.9 percent $(5.1$ percent), in the second and third quartile it was 7.3 percent ( 7.3 percent), and 10.1 percent $(9.8$ percent), respectively. However, the average (median) inflation rate in the high inflation quartile was nearly 70 percent $(28.3$ percent).

The second noteworthy point that emerges from Table 2 is that all the "action" occurs at the extremes. Financial development is typically noticeably greater in the lowest inflation quartile than 
in the two moderate inflation quartiles, and the high inflation quartile has a markedly lower level of financial development than the middle quartiles. However, at moderate rates of inflation (the two middle quartiles), we do not observe large differences in the degree of financial development. This point is illustrated in Figure 1 using $P R I V Y$ as an example. The ratio of credit to private firms divided by GDP, PRIVY, is 0.34 in the low inflation quartile and 0.15 in the high inflation quartile, but is virtually identical in the two middle inflation quartiles. We conclude that there is a clear negative relationship between inflation and financial development, but one which appears to be nonlinear. We investigate this observation in more detail below. ${ }^{12}$

\section{B. Stock Market Data Set: 1970-1993}

\section{Data Description}

The second data set includes measures of stock market development and is taken from Levine and Zervos (1996). It covers the period 1970-93, includes data on 51 countries, and incorporates seven financial performance measures. ${ }^{13}$

$M C A P G D P$ equals the value of listed domestic company shares on each country's major stock exchanges divided by $G D P{ }^{14} M C A P G D P$ measures the overall size of markets. Analysts frequently use this as an indicator of stock market development, although of course $M C A P G D P$ does not measure stock market activity, but merely the value of listed shares. While positively associated with the level of economic development over this sample period (Demirguc-Kunt and Levine 1996), MCAPGDP is not very strongly linked to economic growth (Levine and Zervos 1996).

TVTGDP equals the total value of domestic equities traded on each country's major stock exchanges divided by GDP. The total value traded ratio measures the organized trading of equities as a share of national output. TVTGDP complements the market capitalization ratio (MCAPGDP) 
because TVTGDP reflects the actual volume of market transactions along with the overall size of the market. $^{15}$

$T O R$ equals the total value of domestic shares traded divided by the total value of domestic shares (that is, TVTGDP/MCAPGDP). Thus, TOR measures trading volume relative to the size of the market. Both TVTGDP and TOR are frequently used as indicators of market liquidity-the ability to trade equities easily. The measures complement one another since TVTGDP measures trading relative to the size of the economy and TOR measures trading relative to the size of the market. Both TVTGDP and TOR are very highly correlated with the level of real per capita GDP as well as its rate of growth (Demirguc-Kunt and Levine 1996 and Levine and Zervos 1996).

VOL is a measure of stock market volatility and is computed as a twelve-month rolling standard deviation estimate that is based on market returns. We cleanse the return series of monthly means and twelve months of autocorrelations using the procedure defined by Schwert (1989). Specifically, we estimate a 12 th-order autoregression of monthly returns, $R_{t}$ including dummy variables, $D_{j p}$ to allow for different monthly mean returns:

$$
R_{t}=\sum_{j=1}^{12} a_{j} D_{j t}+\sum_{k=1}^{12} b_{k} R_{t k}+v_{t}
$$

We collect the absolute value of the residuals from equation (1), and then estimate a 12th-order autoregression of the absolute value of the residuals including dummy variables for each month to allow for different monthly standard deviations of returns:

$$
|\hat{v}|=\sum_{j=1}^{12} c_{j} D_{j t}+\sum_{k=1}^{12} d_{k}\left|\hat{v}_{t-k}\right|+\mu_{t}
$$

The fitted values from this last equation give estimates of the conditional standard deviation of equity returns. ${ }^{16}$ 
$I C A P M$ and $I A P M$ measure the degree of integration of each stock market with world financial markets. To compute these measures of stock market integration, we use two asset pricing models: the international capital asset pricing model (ICAPM) and the international arbitrage pricing model $(I A P M)$. The capital asset pricing and arbitrage pricing models imply that the expected return on each asset is linearly related to a benchmark portfolio or linear combination of a group of benchmark portfolios.

Since these models are well known, and since we use the estimation procedures explained by Korajczyk and Viallet (1989) and Korajczyk (1995,1996), we confine ourselves here to a very brief outline of the procedures for constructing ICAPM and IAPM. Let $P$ denote the vector of excess returns on a benchmark portfolio. For the ICAPM, $\mathrm{P}$ is the excess return on a value-weighted portfolio of common stocks. For the IAPM, P represents the estimated common factors based on the excess returns of an international portfolio of assets using the asymptotic principal components technique of Connor and Korajczyk $(1986,1988)$. Given $m$ assets and $T$ periods, consider the following regression:

$$
R_{i, t}=\alpha_{i}+b_{\mathrm{i}} P_{t}+\varepsilon_{i, t}, i=1,2, \ldots, m ; t=1,2, \ldots, T
$$

where $R_{i, t}$ is the excess return on asset $i$ in period $t$ above the return on a risk free or zero-beta asset (an asset with zero correlation with the benchmark portfolio). In perfectly integrated financial markets, capital flows across international borders to equate the price of risk. If stock markets are perfectly integrated, then the intercept in a regression of any asset's excess return on the appropriate benchmark portfolio, $P$, should be zero. Specifically, the IAPM and ICAPM models, along with the assumption of perfect integration imply that

(4) $\quad \alpha_{1}=\alpha_{2}=\ldots=\alpha_{m}=0$. 
Thus, if markets are integrated, $\left|\alpha_{i}\right|$ represents the deviation of expected returns on asset $i$ from the predictions of the ICAPM or LAPM models. Korajczyk and Viallet (1989) refer to $\alpha_{i}$ as the mispricing of asset $i$ relative to the excess returns on the benchmark portfolio, $P$.

Under the assumption that the ICAPM and IAPM are reasonable models of asset pricing, we can interpret estimates of $\left|\alpha_{i}\right|$ as measuring the degree of deviation from a situation of complete financial integration. To compute estimates of stock market integration for each national market, we compute the average of $\left|\alpha_{i}\right|$ across all assets in each country. Thus, the ICAPM and IAPM measures are designed to be negatively correlated with the degree of market integration, or to be positively correlated with market segmentation. ${ }^{17}$

$E Q R T$ is the average monthly rate of growth of the nominal stock market price index for each country. Thus, this measures the nominal rate of return (excluding dividends) from holding the index portfolio of each country's major stock exchange. ${ }^{18}$

\section{Correlations and Quartile Statistics}

Table 3 presents correlations among the stock market variables and inflation. Stock return volatility and international stock market segmentation are positively and significantly correlated with inflation. Although stock market size and liquidity are negatively correlated with inflation, these simple correlations are not significant at the 0.05 level. Nominal stock returns are strongly positively correlated with inflation, with a correlation coefficient of 0.97 . However, we show below that both the weak simple correlations between stock market activity and inflation, and the strong correlation between inflation and nominal equity returns mask a richer and more interesting pattern of relationships.

Table 4 presents means and medians for the rate of inflation and for the various financial development indicators after the data have been sorted by inflation and broken into quartiles. The 
lowest inflation quartile of countries clearly has both the largest (MCAPGDP) and the most liquid stock markets (TVTGDP and TOR). The highest inflation quartile of countries clearly has the smallest and typically the least liquid stock markets. The most substantial differences in the degree of equity market development, however, are between the lowest inflation quartiles, and all the others. This point is illustrated in Figure 2 using the variable TVTGDP. As with the banking development indicators, there is evidence of a negative correlation between inflation and equity market activity, and evidence of nonlinearities in the empirical relationships. There also seem to be some differences in the empirical relationship between inflation and banking development, and between inflation and equity market development. With respect to equity market development, the notable difference is between the low inflation quartile and the other three. However, for the banking development indicators, the lowest (highest) inflation quartiles display much better (less well) developed financial systems than the two middle quartiles.

With respect to the nominal returns on equity, stock return volatility, and the degree of world capital market integration, we observe a somewhat different pattern. Nominal returns, volatility, and market segmentation differ, for the most part, only to a small degree across the lowest inflation quartiles. However, the average volatility of stock returns is more than twice as high in the highest inflation quartile as it is in any other. Market segmentation is also much greater in the two highest inflation quartiles. Similarly, while the average rate of inflation in the third quartile (12.2 percent) is about double that of the first quartile ( 5 percent), nominal equity returns are actually higher in the lowest inflation quartile than they are in the third (8.7 percent versus 7.5 percent). In contrast, the average inflation rate in the fourth quartile is more than 100 percent higher than that in the third quartile (136 percent versus 12 percent), while nominal equity returns are 62.5 percent higher (70 percent versus 7.5 percent). Thus, again, we see nonlinear patterns or, potentially, thresholds in the relationship between inflation and financial market conditions. 


\section{Regressions: Inflation and Financial Market Development}

Our preliminary examination of both the banking and equity market data suggests that inflation and financial market development are negatively related. It also appears that the relationship might be nonlinear. In order to further explore the empirical association between inflation and financial development, we estimate three types of regressions. First, we use simple linear regressions which control for other economic factors that may be associated with financial development to gauge the independent partial correlation between financial development and inflation. Second, we allow for breaks-discrete changes in the slopes and intercepts-in the relationship between inflation and financial development. Such breaks might occur if there are threshold affects associated with the rate of inflation exceeding some critical level. Third, we repeat the first set of regressions replacing the inflation rate with nonlinear transformations-specifically, the inverse inflation rate and the exponential function of the inflation rate-in order to see if these nonlinear specifications better describe the dạta.

\section{A. Banking Data Set: 1960-89}

\section{Simple Linear Regressions}

Table 5 presents regression results when the dependent variable is one of the five financial development indicators. To assess the strength of the partial correlation between these financial development indicators and inflation, we include other variables in the regressions that might be expected to be associated with financial development or with the rate of inflation. Many theoretical analyses (for example, Greenwood and Jovanovic 1990, or Greenwood and Smith 1996) suggest that the level of economic activity may affect financial market development, and clearly it could also affect the rate of inflation. Consequently, we include two variables that are frequently used in crosscountry regressions to control for the level of development (see Barro and Sala-i-Martin 1995): the 
logarithm of initial (1960) real per capita GDP (LRGDP), and the logarithm of initial secondary school enrollment (LSEC). Also, political instability may affect both the level of financial development (LaPorta, deSilanes, Shleifer, and Vishny 1996) and the rate of inflation. To control for political factors that might affect market stability, we include a measure of the number of revolutions and coups (REVC), which is again a commonly used variable in cross-country comparisons (Barro and Sala-i-Martin 1995). Furthermore, various trade and price distortions-other than inflation-may affect the willingness of agents to engage in financial contracting. Consequently, we include the average black market exchange rate premium $(B M P)$ as a general indicator of price, trade, and exchange rate distortions. ${ }^{19}$ Finally, inflation and financial development may be negatively correlated only because both are correlated with fiscal policy, as noted in the introduction. To control for this possibility, we included the ratio of central government expenditure to GDP (GOVY) as an additional explanatory variable in equation (5). ${ }^{20}$ Thus, Table 5 presents parameter estimates from the following regression: ${ }^{21}$

$$
\begin{aligned}
& \text { Financial } \\
& \text { Development }=a+b L R G D P+c L S E C+d R E V C+e B M P+f G O V Y+g P I+u \\
& \text { Indicator }
\end{aligned}
$$

where $u$ is the residual and $a, b, c, d, e, f$, and $g$ are estimated regression coefficients. All tables report White's (1980) heteroskedasticity-consistent t-statistics. (In Table 5, the coefficient on inflation, $g$, has been multiplied by 100 to reduce the number of decimal points.)

As indicated in Table 5, there is a statistically significant negative relationship between inflation and most of the financial development indicators: $P R T Y, L L Y$, and $M 1 Y$ are all significantly negatively associated with inflation after controlling for the level of economic development, political stability, the black market exchange rate premium, and fiscal policy. The financial development 
indicator that excludes demand deposits and currency, $Q L L Y$, and the proportion of credit allocated by banks relative to the central bank, $B A N K$, are not strongly linked with inflation.

However, it is also the case that the economic magnitude of the inflation coefficients is small. For example, a 10 percentage point rise in average inflation over the $1960-89$ period is associated with a fall in the size of the financial development ratio, $L L Y$, of 0.006 , which is less than 2 percent of the sample mean of $L L Y(0.37)$.

We have already argued that there is substantial evidence that any relationship between inflation and financial development is nonlinear. This argument is bolstered by Figure 3, which presents the partial scatter diagram of $L L Y$ against inflation controlling for the other right-hand-side variables. ${ }^{22}$ The partial scatter differs in an important way from a plot of the actual versus the predicted values of the dependent variable from a multivariate regression. The actual versus predicted plot focuses on how the predictions of the multivariate regression differ from the actual values. The partial scatter projects the regression plane-and the actual values-into financial developmentinflation space. Thus, Figure 3 allows us to assess whether there is a linear relationship between inflation and financial development, after controlling for the other factors. In fact, the figure strongly suggests that any relationship which exists is not a simple linear one. High inflation is associated with low financial depth and deep financial markets are associated with low inflation. However, a straight line does not adequately capture the finance-inflation relationship as one moves between low, moderate, and high inflation countries. We now proceed to investigate in more detail the nature of these nonlinearities.

\section{Threshold Regressions}

One possibility is that there are threshold effects associated with the rate of inflation exceeding some "critical" level: that is the finance-inflation relationship may differ depending upon 
whether or not the rate of inflation lies below or above some value. ${ }^{23}$ We next examine this possibility by allowing for the existence of a break in the relationship between financial development and inflation. Specifically, we allow both the slope and the intercept in equation (5) to differ at high and low rates of inflation. To do so, define the dummy variable HIPIXX, by

$$
\begin{array}{cc}
- & 1 \text { if } P I \geq X X \\
H I P I X X= & 0 \text { otherwise. }
\end{array}
$$

We then estimate the regression equation:

$$
\begin{aligned}
& \text { Financial } \\
& \text { Development }=a+b L R G D P+c L S E C+d R E V C+e B M P+f G O V Y \\
& \text { Indicator } \quad+g P I+h H I P I X X+i[(P I) * H I P[X X]+u \text {. }
\end{aligned}
$$

Thus, if inflation is greater than $X X$, the intercept is $(a+h)$, while if inflation is less than $X X$ the intercept is $(a)$. Similarly, if inflation is greater than $X X$, the coefficient on inflation is $(g+i)$, while the slope is $g$ if inflation is less than $X X$. Estimating these "threshold" regressions allows us to examine whether there is an important change in the finance-inflation relationship as inflation exceeds some "critical level" $(X X) .{ }^{24}$ We experimented with critical values ranging from 7.5 percent to 40 percent inflation rates. These different thresholds generally produce very similar results. In Table 6 , we report the results using a critical value of 15 percent inflation, so that countries with inflation rates averaging more than 15 percent per annum over the 1960-89 period are classified as "HIPI15" countries. There are 22 HIPI15 countries. $^{25}$

As shown in Table 6, allowing for a break better captures the finance-inflation relationship than does a simple linear regression. Inflation is negatively associated with all of the financial development indicators in countries with inflation rates of less than 15 percent, and is significantly correlated with PRIVY, $L L Y$, and $Q L L Y$ at the 5 percent level. Moreover, the economic magnitude 
of the finance-inflation relationship is now much larger than in the simple linear specification. Using the same conceptual experiment as before, an increase of ten percentage points in average annual inflation in a "low inflation" country is now associated with a 0.25 fall in the measure of financial depth, $L L Y$, which is more than 60 percent of the mean value of $L L Y$ for the sample.

A further interesting result is that-in countries exceeding the threshold-the partial correlation between inflation and financial development essentially disappears. In particular, note that the sum of the regression coefficients on $P I$ and PIHIPI15 in Table 6 always approximately equals zero (that is, $g+i \approx 0$ ). Table 6 reports Wald $F$ statistics testing the hypothesis that these coefficients do sum to zero, and the data do not reject this hypothesis at any reasonable significance level. This suggests that not only are there threshold effects in the relationship between inflation and financial development, but that once inflation exceeds this threshold, further increases do not further affect the financial system. Of course this does not mean that high inflation is unrelated to financial development:

As is also clear from Table 6 , the coefficient on HIPI15 is significantly negative and economically large for all the financial variables other than $M 1 Y$. For example, the coefficient on the HIPI15 dummy variable is -0.32 in the $L L Y$ regression, while the sample mean for $L L Y$ is 0.37 . Thus countries with inflation rates in excess of the threshold experience a significant reduction in the intercept of the relationship between inflation and financial development. Further, as we changed the inflation threshold from 7.5 to 10 , to 15 , and then to 40 percent inflation, we found a generally smooth and consistent response: the estimated intercept for the countries above the threshold fell and the estimated coefficient on inflation tended to fall in absolute value. This represents additional evidence of a nonlinear relationship between financial development and inflation. ${ }^{26}$

To summarize, there appears to be evidence of a threshold in the empirical relationship between inflation and financial activity. At moderate inflation rates, there is a strong negative 
association between inflation and financial development. For countries whose rate of inflation is above some critical level, the estimated intercept of the banking development relation is much lower than it is for countries below the threshold. Moreover, in economies with rates of inflation beyond this threshold, the partial correlation between inflation and financial activity essentially disappears. Unfortunately, with available data we are unable to determine a "best" threshold. ${ }^{27}$

\section{Another Nonlinear Function}

The evidence in Table 6 suggests that the relationship between financial development and inflation "flattens" at relatively high rates of inflation. There are obviously a number of other functional forms that might capture this property of the data. To investigate one such form we also estimate the regression in equation (5), but with the inflation rate replaced by its inverse (INVPI = 1/PI). Table 7 presents the results of regressions using this simple nonlinear transformation. INVPI enters the BANK, PRIVY, $L L Y$, and $Q L L Y$ equations significantly at the 0.01 significance level. Figure 4 also presents the partial scatter plot of financial depth, $L L Y$, against the inverse inflation rate. The figure indicates that the nonlinear transformation of inflation seems to have a much more consistent relationship with $L L Y$ than the linear specification graphed in Figure 3. Put differently, when we specify the finance-inflation relationship linearly, the actual values do not fall continuously along the estimated regression line. However, when we use the inverse of inflation, the actual values do tend to fall along the predicted path even at moderate inflation rates. This provides further evidence that financial development and inflation are inversely related, and that this relationship is not linear. It appears to flatten at "high" rates of inflation. 


\section{B. Stock Market Data Set: 1970-93 \\ 1. Simple Linear Regressions}

We now repeat our empirical procedures using the equity market data set. Table 8 presents the results from regressing the seven stock market performance indicators on inflation, plus the same set of control variables employed previously.

Clearly the volatility of equity returns is positively associated with inflation. The coefficient on inflation in the volatility regression, however, is economically small. For example, a ten percentage point increase in inflation is associated with a 0.018 increase in volatility, which is less than 3 percent of the sample mean (0.7). Similarly, although inflation enters the stock market liquidity regression (TVTGDP) with a statistically significant coefficient, the inflation-liquidity relationship is economically inconsequential. Stock market size (MCAPGDP) is not significantly linked to inflation, and there are mixed results on the empirical relationship between international capital market integration and inflation. While the ICAPM measure of integration suggests that economies with lower rates of inflation have more integrated capital markets internationally, the results are weaker for the IAPM measure of integration. Finally, the association between nominal stock returns and inflation is statistically significant and economically large. A 10 percentage point increase in inflation is associated with a 13 percentage point increase in nominal stock returns.

\section{Threshold Regressions}

As before, we investigate the possibility that there are threshold effects in the empirical relationship between the equity market variables and inflation. Table 9 reports the results of estimating equation (6) with a 15 percent inflation threshold for the various equity market

variables. ${ }^{28}$ Evidently, incorporating a threshold effect substantially alters the results. Inflation now enters the TVTGDP regression with a negative, significant, and economically large coefficient. The 
coefficient implies that a 10 percentage point rise in inflation (while remaining below the threshold) is associated with a fall in TVTGDP of 0.24 , which is large considering that the sample standard deviation is 0.19 . Similarly, the regressions indicate that inflation is significantly related to $M C A P G D P$ and TOR, at the 0.10 level, with correspondingly large coefficients. Thus, marginal increases in inflation are associated with economically meaningful reductions in market size and liquidity once we allow for the possibility of threshold effects. In addition, the coefficients on HIPI15 indicate that, on average, countries with inflation rates in excess of 15 percent have discretely and significantly smaller intercept terms than do countries with lower rates of inflation. For example, the coefficient on $H I P I 15$ in the $M C A P G D P$ regression is -0.56 , whereas the sample mean of $M C A P G D P$ is 0.33 .

As in the banking regressions, the threshold regressions employing $M C A P G D P, T V T G D P$, and $T O R$ indicate that the finance-inflation relationship flattens significantly at rates of inflation in excess of 15 percent. Indeed, in the $M C A P G D P$ regression we do not reject the hypothesis that the coefficients on $P I$ and $P I H I P I 15$ sum to zero. And, while the data do reject the hypothesis that the coefficients on $P I$ and PIHIPI15 sum to zero in the TVTGDP and TOR regressions at the 6 percent significance level, the economic size of their sum is very small. For example, the coefficient on $P I$ in the TOR regression -3.38 and the coefficient on PIHIPI15 is 3.36. This suggests that once inflation exceeds 15 percent, further increases are not associated with significant further changes in stock market liquidity.

The threshold regression involving nominal equity returns offers an interesting contrast. We have already observed (see Table 4) that the relationship between inflation and nominal equity returns is weak at low-to-moderate rates of inflation, and becomes more pronounced at higher rates of inflation. The regression in Table 9 provides further confirmation of this finding. For countries with average annual inflation rates of less than 15 percent, there is no significant relationship between the 
long-run rate of inflation and the nominal return on equity. Once the rate of inflation exceeds 15 percent the intercept term declines: the coefficient on HIPI15 is fairly large, negative, and statistically significant. However, for economies with rates of inflation already in excess of 15 percent, marginal increases in inflation are matched by even greater than one-for-one $(1.36=0.984+0.376)$, increases in nominal stock returns.

Many studies of equity returns using time series data for individual countries have found that the nominal equity return is essentially uncorrelated with inflation (see Amihud 1996 or Boudoukh and Richardson 1993, and the references they cite). Most such studies have focused on economies with low rates of inflation (however see Amihud 1996 for one exception). Our results on longer-term relationships seem consistent with this finding, for low inflation countries. However, for countries with sustained inflation rates in excess of 15 percent, matters seem very different.

Finally, regressions involving the market segmentation measures have the feature that few of the inflation variables enter significantly. We do not regard these results with much confidence, simply because the sample sizes are quite small.

We conclude that there is evidence of both a negative correlation between inflation and equity market development, and of threshold effects in this relationship. Even in low inflation countries, marginal increases in inflation rates are associated with substantially less active stock markets. And high inflation economies (those with average inflation rates in excess of 15 percent) on average have significantly smaller and less liquid equity markets than their lower inflation counterparts. However, it is also the case that, in high inflation countries, incremental increases in the rate of inflation have only small incremental effects on stock market development. Finally, the relationship between nominal equity returns and inflation is almost a mirror image of the inflation-liquidity link. More inflation in a low-inflation environment is not matched by greater nominal equity returns. In high- 
inflation economies, however, equity returns move at least one-for-one with marginal increases in inflation rates.

\section{Regressions Using Nonlinear Transformation}

The observation that the relationship between equity market development and inflation "flattens" as inflation rises can, of course, be captured in other ways. Again, as a specific possibility, we replace $P I$ with its inverse $(I N V P I=1 / P I)$ in equation (5), and redo these regressions for the stock market size and liquidity variables (MCAPGDP, TVTGDP, and TOR). For nominal equity returns, which showed signs of becoming more sensitive to marginal increases in inflation at higher inflation rates, we replace $P I$ with its exponential $(E X P P I=E X P\{P I\})$. We also use the exponential for equity return volatility and the IAPM and ICAPM market segmentation measures because they are positively associated with inflation (Table 8). Table 10 reports the results. Clearly both MCAPGDP and TVTGDP are significantly positively correlated with the inverse inflation rate, and the volatility of equity returns, the ICAPM segmentation index, and nominal equity returns are all significantly positively correlated with EXPPI. The estimated coefficients also appear to be large in economic terms. For example, our point estimates suggest that a permanent increase in the inflation rate from 10 percent to 20 percent will on average be associated with a fall in TVTGDP of 0.09 . (Its sample mean is 0.11.) However, a rise in the rate of inflation from 38 percent (its sample mean) to 48 percent would -reduce TVTGDP by only $0.006 .^{29}$ This, of course, reflects the "flattening" in this relationship as inflation rises.

\section{Sensitivity Analyses}

We have explored the sensitivity of our results with respect to various modifications in the specification of the regressions, the sample period, and the set of countries considered. For brevity, we do not report these results here. However, we have redone the regressions involving the banking 
variables for each of the decades 1960-69, 1970-79, and 1980-89. For each sub-period the results are qualitatively very similar to those for the entire sample, with the exception of the period 1960-69. During that decade, the empirical relationship between inflation and the banking development indicators is substantially attenuated. Of course, as we have already noted, during the sixties the average rate of inflation in the highest inflation quartile was only 14 percent. Thus we regard this finding as further confirmation of our other results. ${ }^{30}$

For the equity market data, we looked at $1970-79,1980-89$, and 1990-93 as separate subperiods. The results for each sub-period qualitatively resemble those for the entire sample.

We have reported regression results where both the left-hand side variable, and the rate of inflation are in levels. Replacing these variables with their logarithms did not alter our conclusions. Also, to further check for evidence of a nonmonotonic relationship between inflation and financial development, we added quadratic terms to the linear regressions. Those results also strongly indicate that the relationship between inflation and financial market performance is nonlinear: marginal increases in inflation are associated with much smaller declines in financial development at higher inflation rates.

We tested for the potential effects of outliers in two ways. First, we removed very highinflation countries (countries with average annual inflation rates of greater than 100 percent) from the sample, and re-estimated all of the regressions. For the banking development data set, these countries included Argentina, Brazil, Bolivia, and Peru; for the stock market data set, these countries included Argentina, Brazil, and Sri Lanka. Omission of these countries did not materially affect our findings. We also tested for the affect of influential data points using the procedure suggested by Belsley et al. (1980), and described in Greene (1993, p. 287-288), using a critical value of 2.5. Our conclusions are unaffected by removing country observations that exert a large effect on each equation's residuals. 
Finally, a natural question is whether it is the level of inflation, or its variability that is correlated with our measures of financial market development. This question is intrinsically difficult to address, since the correlation in our sample between inflation and its standard deviation is 0.97 . However, we re-estimated most of our regressions with inflation replaced by its standard deviation. Again, the results are qualitatively very similar, although the correlation between the financial market variables and the standard deviation of inflation is generally slightly weaker than the correlation between these variables and the rate of inflation.

\section{Conclusions}

It is empirically well-established that there is a strong positive correlation between the level of an economy's financial development, and its level $\longrightarrow$ or rate of growth-of real development. It is also well-documented that inflation and long-run real performance measures are negatively correlated, at least at high enough rates of inflation. We have attempted here to add the third side to the triangle by investigating the empirical relationship between the long-run rate of inflation, and the performance of an economy's financial system.

The evidence indicates that there is a significant, and economically substantial, negative relationship between inflation and financial development. This correlation emerges essentially independently of the time period considered, the empirical procedure employed, or the set of variables that appear as additional explanators. It is also not sensitive to the inclusion or exclusion of oil producing countries, or the inclusion or exclusion of countries that have experienced very high rates of inflation. Finally, this correlation emerges even though we attempt to control for fiscal considerations. Thus we conclude that there is a preponderance of evidence that inflation and financial market performance display a strongly negative association. 
We have found that the empirical relationship between inflation and financial market activity is highly nonlinear. In particular, we find that the relationship becomes less pronounced at higher rates of inflation. We have also shown that there is a very close correspondence between inflation and nominal equity returns. In simple correlations and simple linear regressions this correspondence is almost one-for-one. These broad cross-country results differ from time-series studies of a much smaller set of countries which find little correlation between inflation and nominal stock returns. The threshold regressions provide a clue for resolving these seemingly contradictory findings. In lowinflation countries, more inflation is not matched by greater nominal equity returns, which is consistent with earlier findings. In high-inflation economies, however, nominal stock returns move more than one-for-one with marginal increases in inflation rates. We plan to conduct time-series studies of this broad sample of countries in future work.

There are several issues that cannot be sorted out with the methods we have employed. For example, the correlation between inflation and its standard deviation in our sample is 0.97 . Thus all of the statements we have made about the correlation between the rate of inflation and various financial market conditions apply almost equally to the variability of inflation. Moreover, we cannot ascertain whether the threshold regressions, or the smooth nonlinear regressions, provide the "best fit" of the data. That task would require fitting different functions for each dependent variable, instead of the broad brush "one function fits all variables" approach we have employed in this study.

Another issue that merits much more consideration, and that would have to be investigated by other means, is the nature of the empirical linkages between inflation, financial development, and long-run growth. Our evidence suggests that inflation and financial market conditions are quite negatively correlated—even, and perhaps especially —at low to moderate rates of inflation. We also know that financial market factors are strong predictors of future growth performance. And yet a significantly negative correlation between inflation and real activity seems to be observed only when 
inflation is fairly high-possibly as high as 40 percent (Bruno and Easterly 1995). What can account for this pattern of correlations? This must remain a topic for future investigation.

There is, of course, a variety of possible extensions of this analysis. In future research we hope to exploit the time series, as well as the cross-sectional aspects of our data set, and to analyze shorter-run as well as longer-run empirical interactions between inflation and the development of the financial system. 


\section{Footnotes}

${ }^{1}$ See Cameron (1967) for some historical evidence. Goldsmith (1969), Atje and Jovanovic (1993), King and Levine (1993a,b,c) Demirguc-Kunt and Levine (1993), Rajan and Zingales (1996), Neusser and Kugler (1996), Levine and Zervos (1996), and Levine (1997) provide an array of evidence based on more recent data.

${ }^{2}$ See, for example, DeGregorio (1992), Wynne (1993), Fischer (1993), Barro (1995), and especially Bullard and Keating (1995) or Bruno and Easterly (1995).

${ }^{3}$ It is often argued that high real returns are conducive to growth (McKinnon 1973, Shaw 1973, Fry 1995). Thus evidence that equity returns do not adjust to compensate for predictable inflation suggests an additional mechanism by which inflation might affect growth.

${ }^{4}$ Examples of the kinds of models we have in mind include Azariadis and Smith (1996); Choi, Smith, and Boyd (1996); Boyd and Smith (forthcoming); and Huybens and Smith (1996).

${ }^{5}$ See Bencivenga and Smith (1992); Roubini and Sala-i-Martin (1995); and Chari, Jones, and Manuelli (1996) for models generating these kinds of results.

${ }^{6}$ The countries included in this data set are listed in the Appendix.

${ }^{7}$ IFS line 34 divided by IFS line $99 \mathrm{~b}$.

${ }^{8}$ IFS line 551 , or IFS lines $34+35$ if 351 is unavailable, divided by IFS line $99 \mathrm{~b}$.

${ }^{9}$ IFS line $32 \mathrm{~d}$ divided by IFS line $99 \mathrm{~b}$. Note, that while in principal this variable excludes credits to state owned enterprises, this is not done consistently across countries due to measurement and definitional problems.

${ }^{10} I F S 22 a+\ldots+22 f /[(22 a+\ldots+f)+(12 a+\ldots+f)]$.

${ }^{11}$ The major oil exporters are frequently omitted from broad cross-country studies because of the disproportionately large effect of one commodity on economic performance. The countries are 
Algeria, Gabon, Indonesia, Iran, Iraq, Kuwait, Nigeria, Oman, Saudi Arabia, and Venezuela. The results we report are not materially affected by including these countries in the sample.

${ }^{12} \mathrm{We}$ also produced these quartile tables data averaged over different decades: the 1960 s, 1970s, and 1980s. The results are very similar to those in Table 2 except that average inflation rose from about five percent in the 1960s, to 15 percent in 1970s, to over 44 percent in the 1980s. This trend primarily reflects a rise in the highest inflation countries. Specifically, the average annual inflation rate of the fourth quartile of countries rose from about 14 percent in the 1960s, to 39 percent in 1970s, to almost 146 percent in the 1980s. The patterns apparent in Table 2 also emerge when we consider the 1970s and 1980s separately. For the 1960s these patterns are attenuated; this is not very surprising in light of the fact that the average inflation rate in the highest inflation quartile was only 14 percent over this decade.

${ }^{13}$ Countries included in this data set are indicated with an asterisk in the appendix.

${ }^{14}$ This variable is taken from the International Finance Corporation's Emerging Markets Data Base.

${ }^{15}$ This variable is taken from the International Finance Corporation's Emerging Markets Data Base.

${ }^{16}$ Further, as in Schwert (1989), we use iterated weighted least squares estimates, iterating three times between (1) and (2), to obtain more efficient estimates. Stock market index values are taken from the International Finance Corporation's Emerging Markets Data Base and from the International Monetary Fund's International Financial Statistics.

${ }^{17}$ It is important to recognize that the ICAPM and IAPM integration measures rely on equilibrium models of asset pricing that the data sometimes reject as good representations of the pricing of risk. However, for this paper, we seek a numerical index of, for example, how much better integrated the U.S. is with world financial markets than is, say, Nigeria. Thus, we are not concerned 
with whether the index is based at zero, or with the possibility that the stock market integration measures include a constant bias. In either case the ICAPM and IAPM integration measures can still provide sound information permitting cross-country comparisons of the degree of market integration. The source of these values is Korajczyk (1994).

${ }^{18}$ Sources: International Finance Corporation's Emerging Markets Data Base and the International Monetary Fund's International Financial Statistics.

${ }^{19}$ Real per capita GDP is from Summers and Heston (1988). Secondary school enrollment and the number of revolutions and coups per year are from Barro (1991). The black market exchange rate premium is from the World Bank (1991).

${ }^{20} \mathrm{We}$ would prefer to use a measure of the government budget deficit rather than total government expenditures. However, during the 1960 s and 1970s, data on central government budget deficits are available for only about 85 percent of our sample. With this smaller cross-section, inflation is not significantly correlated with our financial development indicators, independently of whether or not the government budget deficit is included as a regressor. However, it is possible to run our regressions using the government budget deficit rather than government expenditure over the 1980s. When this is done the results are qualitatively very similar to those reported here.

${ }^{21}$ In estimating equation (5) by ordinary least squares, we are implicitly taking the stand that the rate of inflation is an exogenous variable. Given our focus on time-averaged data (and hence our search for longer-run relationships), we believe that there are several defenses available for this position. For instance, the literature cited in footnote 5-and, indeed, almost all of the theoretical literature on monetary growth models-takes the view that the long-run rate of money growth is an exogenously chosen instrument of policy. If this is correct, and if the long-run rate of economic growth (although not necessarily the per-capita capital stock) is independent of monetary factors, then 
the long-run rate of inflation can legitimately be treated as exogenous. The assumption that long-run growth is not affected by monetary policy is, of course, a basic monetarist tenet.

If the government has an exogenously given deficit to monetize, as in the literature cited in footnote 6 , then the long-run rate of inflation cannot typically be set as an independent instrument of policy. However, if the ratio of government bonds to base money is set exogenously through open market operations, if the ratio of the government budget deficit to GDP is exogenous, if long-run real interest rates are independent of monetary factors, and if long-run velocity is constant, then the rate of inflation is not affected by financial market conditions. It is therefore a legitimate regressor in (5). The notions that real rates of interest are not affected by monetary factors in the long-run, and that long-run velocity is constant, are both asserted to receive strong empirical support by Friedman and Schwartz $(1963,1982)$.

${ }^{22}$ Specifically, we regress $L L Y$ on a constant, $L R G D P, L S E C, R E V C$, GOVY, and BMP and collect the residuals $u(L)$. Then we regress $P I$ on the same set of explanators and collect the residuals $u(P)$. Finally, we plot $u(L)$ against $u(P)$ and display the associated regression line. This is the projection of the regression plane from equation 5 into $L L Y-P I$ space.

${ }^{23}$ Evidence of threshold effects in the relationship between inflation and real performance is provided by Bruno and Easterly (1995) and Bullard and Keating (1995). Theoretical results suggesting that such threshold effects might exist in (5) appear in Azariadis and Smith (1996); Choi, Smith, and Boyd (1996); Boyd and Smith (forthcoming); and Huybens and Smith (1996).

${ }^{24}$ As noted by Greene (1993, p. 236), if the high-inflation group has the same error disturbance variance as the low-inflation group, then pooling the observations of the two groups increases the efficiency of the regression's standard error. However, if the variances differ, then pooling will produce biased estimates of both disturbance variances. 
${ }^{25}$ These countries are Argentina, Bolivia, Brazil, Chile, Colombia, Ecuador, Ghana, Gabon, Iceland, Israel, Indonesia, Mexico, Nicaragua, Peru, Sierre Leone, Somalia, Sudan, Turkey, Uganda, Uruguay, Zaire, and Zambia.

${ }^{26}$ When evaluated at some of the thresholds discussed in the text, the estimated equations sometimes predict that the banking development measures actually rise rather than fall as the rate of inflation crosses its threshold level. This can occur because the reduction in the intercept may be small relative to the increase in the slope coefficient at the threshold rate of inflation. However, we do not think that too much should be made of this result, because it is highly sensitive to the specific choice of the threshold inflation rate. We have not tried to estimate a threshold because different choices for the critical rate of inflation produce relatively similar results.

We have also experimented with other nonlinear relationships between financial development and inflation-such as quadratics-that impose continuity. These also strongly reject the null hypothesis of a linear relationship, and indicate that the empirical relationship between inflation and financial development flattens as the rate of inflation rises.

${ }^{27}$ We also experimented with the introduction of multiple thresholds. This produced no important differences in results. The outcome of the "quartile sorting" indicates that multiple thresholds are a possibility. However, the very small number of observations in any "piece" of a spline-type regression suggests that it would be difficult to observe significant differences between different "pieces" of the spline.

${ }^{28}$ For the stock market data set, there are 13 countries with average annual inflation rates above 15 percent for the 1970-1993 period: Argentina, Brazil, Chile, Colombia, Costa Rica, Israel, Jamaica, Sri Lanka, Mexico, Nigeria, Peru, Turkey, and Venezuela.

${ }^{29}$ To compute this, note that the derivative of TVTGDP with respect to inflation in the INVPI regression is $\partial(T V T G D P)=\left\{-[0.009] /[P]^{2}\right\} \partial P I$. Then, we assume that $\partial P=0.10$ and evaluate this 
derivative at the sample average for $P I(0.383)$. Then $\partial(T V T G D P)=\left\{-[0.009] /[0.383]^{2}\right\}(0.10)=$ 0.006 .

${ }^{30} \mathrm{By}$ the same token, when the 1960 s are removed from the sample, the empirical relationship between inflation and financial market conditions is even stronger than what we have reported. Similarly, when we replicate the tests with the banking data set over the equity market sample period, 1970-1993, the results are generally even stronger than reported here. 


\section{REFERENCES}

Aiyagari, S. Rao; Braun, Toni; and Eckstein, Zvi. 1996. Transaction services, inflation, and welfare. Research Department Working Paper 551. Federal Reserve Bank of Minneapolis.

Amihud, Yakov. 1996. Unexpected inflation and stock returns revisited: Evidence from Israel. Journal of Money, Credit, and Banking 28 (1): 22-33.

Atje, Raymond, and Jovanovic, Boyan. 1993. Stock markets and development. European Economic Review 37 (April): 632-40.

Azariadas, Costas, and Smith, Bruce. 1996. Private information, money and growth: Indeterminacies, fluctuations, and the Mundell-Tobin effect. Journal of Economic Growth 1: 309-22.

Barro, Robert J. 1991. Economic growth in a cross section of countries. Quarterly Journal of Economics 56 (May): 407-43.

Barro, Robert J. 1995. Inflation and economic growth. Bank of England Quarterly Bulletin (May): 166-76.

Barro, Robert J., and Sala-I-Martin, Xavier. 1995. Economic Growth. New York: McGraw-Hill.

Belsley, D.; Kuh, E.; and Welsch, R. 1980. Regression diagnostics: Identifying influential data and sources of collinearity. New York: Wiley.

Bencivenga, Valerie R., and Smith, Bruce D. 1992. Deficits, inflation, and the banking system in developing countries: The optimal degree of financial repression. Oxford Economic Papers $44,767-90$.

Boudoukh, Jacob, and Richardson, Matthew. 1993. Stock returns and inflation: A long horizon perspective. American Economic Review, 1346-55.

Boyd, John H., and Smith, Bruce D. Forthcoming. Capital market imperfections in a monetary growth model. Economic Theory. 
Breen, William; Glosten, Lawrence R.; and Jagannathan, Ravi. 1989. Economic significance of predictable variations in stock index returns. Journal of Finance XLIV (December, No. 5): 1177-89.

Bruno, Michael, and Easterly, William. Inflation crises and long-run growth. Journal of Monetary Economics, forthcoming.

Bullard, James, and Keating, John. 1995. The long-run relationship between inflation and output in postwar economies. Journal of Monetary Economics.

Cameron, Rondo, et al. 1967. Banking in the early stages of industrialization: a study in comparative economic history. New York: Oxford University Press.

Chari, V. V.; Jones, Larry; and Manuelli, R. 1996. Inflation, growth, and financial intermediation. Federal Reserve Bank of St. Louis Review 78: 41-58.

Choi, Sangmok; Smith, Bruce; and Boyd, John. 1996. Inflation, financial markets, and capital formation. Federal Reserve Bank of St. Louis Review 78: 9-35.

Connor, Gregory, and Korajczyk, Robert A. 1986. Performance measurement with the arbitrage pricing theory: A new framework for analysis. Joumal of Financial Economics 15, 373-94. 1988. Estimating pervasive economic factors with missing observations. Department of Finance Working Paper 34. Northwestern University.

De Gregorio, Jose. 1992. The effects of inflation on economic growth. European Economic Review $36(2-3): 417-24$.

Demirguc-Kunt, Asli, and Levine, Ross. 1996a. Stock market development and financial intermediaries: Stylized facts. World Bank Economic Review 10 (May): 291-322.

1996b. Stock markets, corporate finance, and economic growth: An overview. World Bank Economic Review 19 (May): 223-40. 
Demirguc-Kunt, Asli, and Maksimovic, Vojislav. 1996. Financial constraints, uses of funds, and firm growth: An international comparison. Manuscript. Washington, D.C.: World Bank.

English, William B. 1996. Inflation and financial sector size. Finance and Economics Discussion Series No. 96-16, Federal Reserve Board, Washington, D.C.

Erb, Claude B; Harvey, Campbell R.; and Viskanta, Tadas E. 1995. Inflation and world equity selection. Financial Analysts Journal 51(6) (November-December): 28-42.

Fischer, Stanley. 1993. The role of macroeconomic factors in growth. Journal of Monetary Economics 32 (December): 485-511.

Friedman, Milton, and Schwartz, Anna J. 1963. A monetary history of the United States, 1867-1960. Princeton, NJ: Princeton University Press.

1982. Monetary trends in the United States and the United Kingdom: Their relationship to income, prices, and interest rates, 1867-1975. Chicago, IL: University of Chicago Press.

Fry, Maxwell J. 1995. Money, interest, and banking in economic development. Baltimore, MD: John Hopkins University Press.

Goldsmith, Raymond, W. 1969. Financial structure and development. New Haven, CT: Yale University Press.

Greene, William. 1993. Econometric analysis. Englewood Cliffs, NJ: Prentice Hall, Inc., 2nd. At Greenwood, Jeremy, and Jovanovic, Boyan. 1990. Financial development, growth, and the distribution of income. Journal of Political Economy 98 (October): 1076-1107.

Greenwood, Jeremy, and Smith, Bruce. 1996. Financial markets in development, and the development of financial markets. Journal of Economic Dynamics and Control.

Huybens, Elisabeth, and Smith, Bruce. 1996. Financial market frictions, monetary policy, and capital accumulation in a small open economy. Manuscript. 
International Finance Corporation. Various years. Emerging markets data base. Washington, D.C. International Monetary Fund. Various years. International financial statistics. Washington, D.C. Jovanovic, Boyan and Ueda, Masako. 1996. Contracts and money. Manuscript. New York University.

King, Robert G., and Levine, Ross. 1993a. Financial intermediation and economic development. In Financial intermediation in the construction of Europe, ed. Colin Mayer and Xavier Vives. London: Centre for Economic Policy Research.

- 1993b. Finance and growth: Schumpeter might be right. Quarterly Journal of Economics 108 (August): 717-38.

1993c. Finance, entrepreneurship, and growth: theory and evidence. Journal of Monetary Economics 32 (December): 513-42.

Korajczyk, Robert A. 1995. A measure of stock market integration. Manuscript. Northwestern University.

- 1996. A measure of stock market integration. World Bank Economic Review 10 (May): 267-89.

Korajczyk, Robert A., and Viallet, Claude J. 1989. An empirical investigation of international asset pricing. Review of Financial Studies 2, 553-85.

Laporta, Rafael; Lopez-de-Sịlanes, Florencio; Shleifer, Andrei; and Vishny, Robert W. 1996. Law and finance. Working Paper 5661. National Bureau of Economic Research.

Levine, Ross. 1997. Financial development and economic growth: Views and agenda. Journal of Economic Literature.

Levine, Ross, and Renelt, David. 1992. A sensitivity analysis of cross-country growth regressions. American Economic Review 82 (September): 942-63. 
Levine, Ross, and Zervos, Sara. 1994. Looking at the facts: What we know about policy and growth from cross sectional analysis. In Economic growth and the structure of long-term development, ed. R. Solow and L. Pasinetti, pp. 22-44. United Kingdom: MacMillan Press. 1996. Stock markets, banks, and economic growth. Manuscript. Washington, D.C.: World Bank.

McKinnon, Ronald I. 1973. Money and capital in economic development. Washington, DC: Brookings Institution.

Neusser, Klaus, and Kugler, Maurice. 1996. Manufacturing growth and financial development: Evidence from OECD countries. Manuscript. University of Bern.

Rajan, Raghuram G., and Zingales, Luigi. 1996. Financial dependence and growth. Manuscript. University of Chicago.

Roubini, Nouriel, and Sala-I-Martin, Xavier. 1995. A growth model of inflation, tax evasion, and financial repression. Journal of Monetary Economics 35, 275-301. 1992. Financial repression and economic growth. Journal of Development Economics $39,5-30$.

Schwert, William. 1989. Why does stock market volatility change over time? Journal of Finance 44 (5): 1115-53.

Shaw, Edward S. 1973. Financial deepening in economic development. New York: Oxford University Press.

Summers, Robert, and Heston, Alan. 1988. The Penn world table (mark 5): An expanded set of international comparisons, 1950-1988. Quarterly Journal of Economics 106 (2): 327-68.

White, Halbert. 1980. A heteroskedasticity-consistent covariance matrix and direct tests for heteroskedasticity. Econometrica 48, 817-38.

World Bank. Various years. National accounts data base. Washington, D.C. 
World Bank. World development report 1991. New York: Oxford University Press.

Wynne, Mark. 1993. Price stability and economic growth. The Southwest Economy, Federal Reserve Bank of Dallas. 
Country List

\begin{tabular}{|c|c|c|c|c|c|c|c|c|}
\hline 1 & AFG & Afghanistan & 40 & HTI & Haiti & 80 & PRY & Paraguay \\
\hline 2 & DZA & Algeria & 41 & HND & Honduras & 81 & PER & Peru* \\
\hline 3 & $\mathrm{AGO}$ & Angola & 42 & HKG & Hong Kong* & 82 & PHL & Philippines** \\
\hline 4 & ARG & Argentina** & 43 & ISL & Iceland & 83 & PRT & Portugal*** \\
\hline 5 & AUS & Australia** & 44 & IND & India** & 84 & RWA & Rwanda \\
\hline 6 & AUT & Austria* & 45 & IDN & Indonesia** & 85 & SAU & Saudi Arabia \\
\hline 7 & BGD & Bangladesh* & 46 & $\mathrm{IRN}$ & Iran & 86 & SEN & Senegal \\
\hline 8 & BRB & Barbados & 47 & IRQ & Iraq & 87 & SLE & Sierra Leone \\
\hline 9 & BEL & Belgium* & 48 & IRL & Ireland & 88 & SGP & Singapore* \\
\hline 10 & $\mathrm{BOL}$ & Bolivia & 49 & ISR & Israel* & 89 & SOME & Somalia \\
\hline 11 & BWA & Botśwana & 50 & ITA & Italy* & 90 & $\mathrm{ZAF}$ & South Africa* \\
\hline 12 & $\mathrm{BRA}$ & Brazil** & 51 & JAM & Jamaica* & 91 & ESP & Spain* \\
\hline 13 & $\mathrm{BDI}$ & Burundi & 52 & JPN & Japan** & 92 & LKA & Sri Lanka* \\
\hline 14 & CMR & Cameroon & 53 & JOR & Jordan** & 93 & SDN & Sudan \\
\hline 15 & CAN & Canada* & 54 & KEN & Kenya & 94 & SWZ & Swaziland \\
\hline 16 & CAF & Cent. Afr. Rep. & 55 & KOR & Korea** & 95 & SWE & Sweden* \\
\hline 17 & $\mathrm{TCD}$ & Chad & 56 & KWT & Kuwait & 96 & $\mathrm{CHE}$ & Switzerland* \\
\hline 18 & $\mathrm{CHL}$ & Chile** & 57 & LSO & Lesotho & 97 & SYR & Syria \\
\hline 19 & $\mathrm{COL}$ & Colombia** & 58 & LBR & Liberia & 98 & OAN & Taiwan** \\
\hline 20 & COG & Congo & 59 & LUX & Luxembourg* & 99 & TZA & Tanzania \\
\hline 21 & CRI & Costa Rica* & 60 & MDG & Madagascar & 100 & THA & Thailand** \\
\hline 22 & CIV & Cote D'Ivoire* & 61 & MWI & Malawi & 101 & TGO & Togo \\
\hline 23 & CYP & Cyprus & 62 & MYS & Malaysia** & 102 & TTO & Trin. and Tobago \\
\hline 24 & DEN & Denmark* & 63 & MLI & Mali & 103 & TUN & Tunisia \\
\hline 25 & DOM & Dominican Rep. & 64 & MLT & Malta & 104 & TUR & Turkey** \\
\hline 26 & $\mathrm{ECU}$ & Ecuador & 65 & MRT & Mauritania & 105 & UGA & Uganda \\
\hline 27 & EGY & Egypt* & 66 & MUS & Mauritius & 106 & GBR & United Kingdom ${ }^{* * *}$ \\
\hline 28 & SLV & El Salvador & 67 & MEX & Mexico** & 107 & USA & United States** \\
\hline 29 & ETH & Ethiopia & 68 & MAR & Morocco* & 108 & URY & Uruguay \\
\hline 30 & FJI & Fiji & 69 & $\mathrm{MOZ}$ & Mozambique & 109 & VEN & Venezuela** \\
\hline 31 & FIN & Finland* & 70 & NLD & Netherlands* & 110 & YEM & Yemen \\
\hline 32 & FRA & France* & 71 & NZL & New Zealand* & 111 & ZAR & Zaire \\
\hline 33 & GAB & Gabon & 72 & NIC & Nicaragua & 112 & $\mathrm{ZMB}$ & Zambia \\
\hline 34 & GMB & Gambia & 73 & NER & Niger & 113 & ZWE & Zimbabwe** \\
\hline 35 & DEU & Germany* & 74 & NGA & Nigeria** & 114 & BUR & Burma \\
\hline 36 & GHA & Ghana & 75 & NOR & Norway* & 115 & GUY & Guyana \\
\hline 37 & GRC & Greece** & 76 & $\mathrm{OMN}$ & Oman & 116 & BEN & Benin \\
\hline 38 & GTM & Guatemala & 77 & PAK & Pakistan** & 117 & HVO & Burkina Faso \\
\hline \multirow[t]{2}{*}{39} & GNB & Guinea-Bissau & 78 & PAN & Panama & 118 & NPL & Nepal \\
\hline & & & 79 & PNG & Pap. New Guinea & 119 & SUR & Suriname \\
\hline
\end{tabular}

Note: Although the banking data set includes information on all of the listed countries, some countries do not report some variables so that the sample of countries varies in the regressions.

An asterisk (*) indicates that a country is included in the stock market data set.

Two asterisks (**) indicates inclusion in the stock market data set and in the subset of countries for which there are ICAPM and IAPM estimates. 


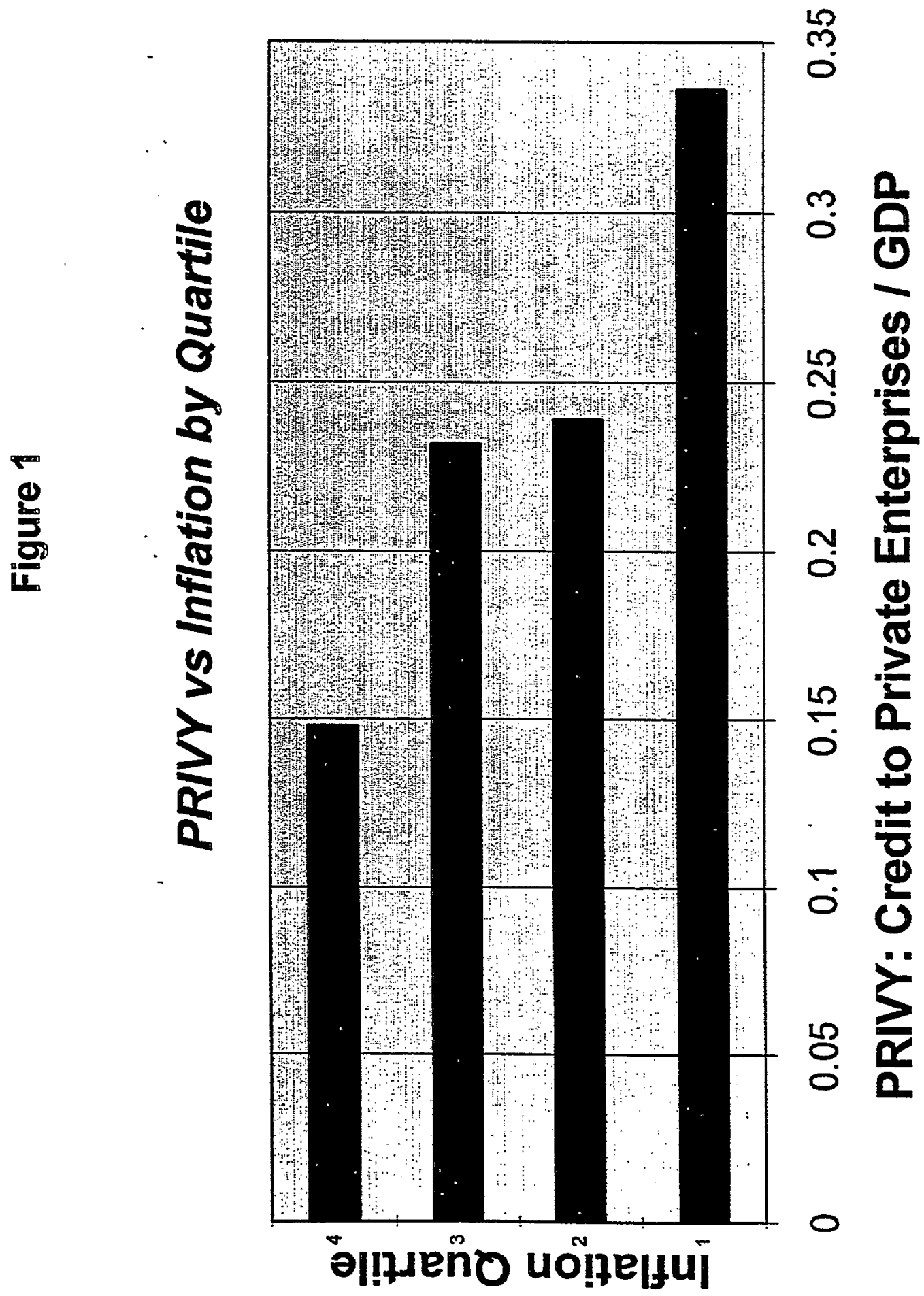

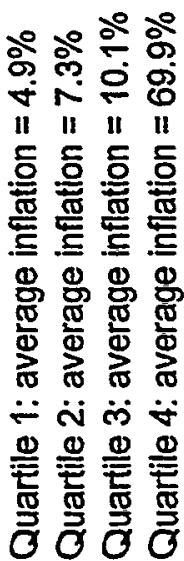




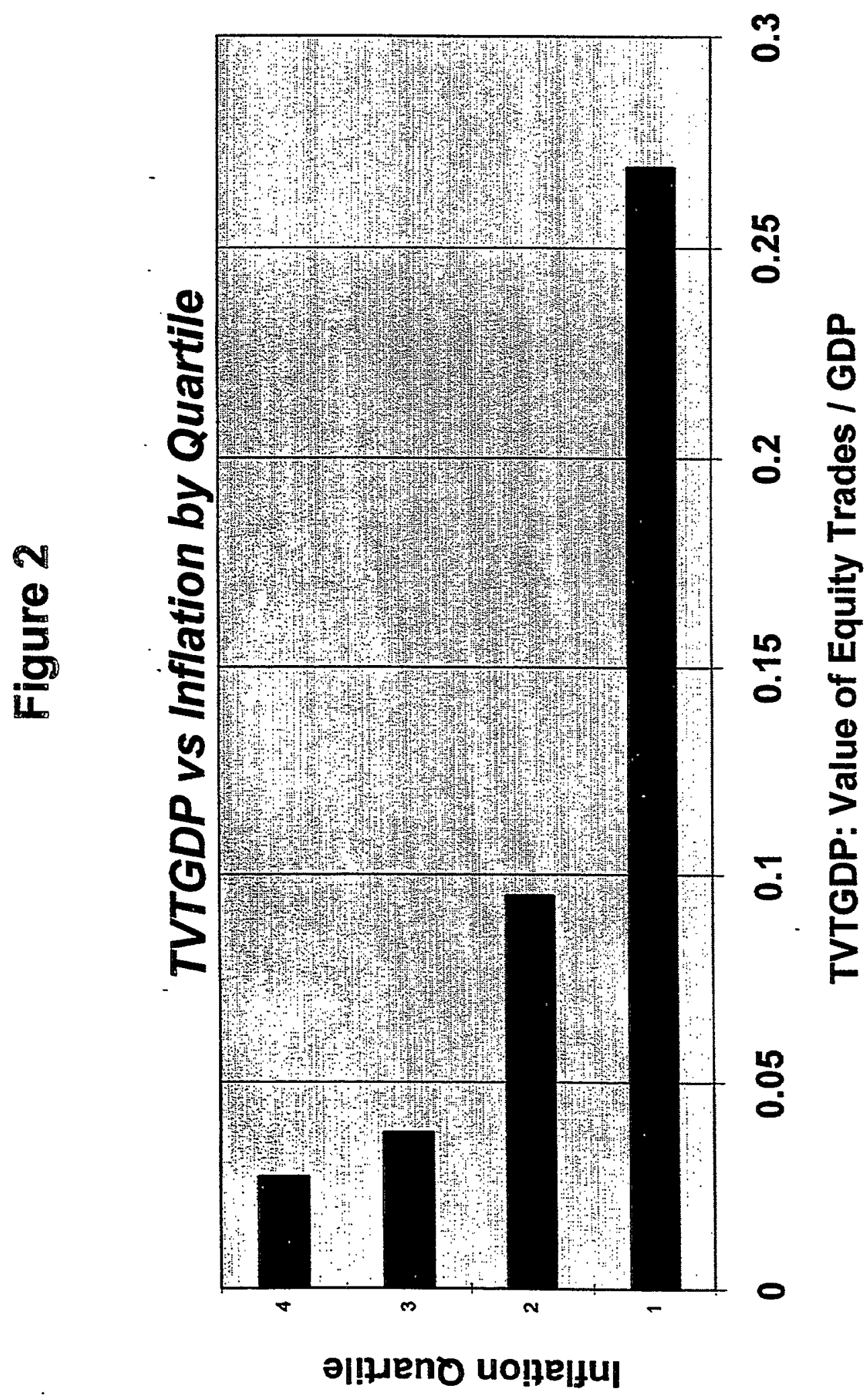

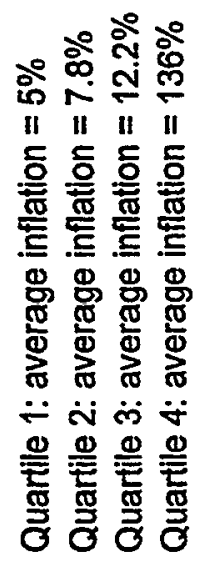


Figure 3: Partial Scatter: Financial Depth vs Inflation

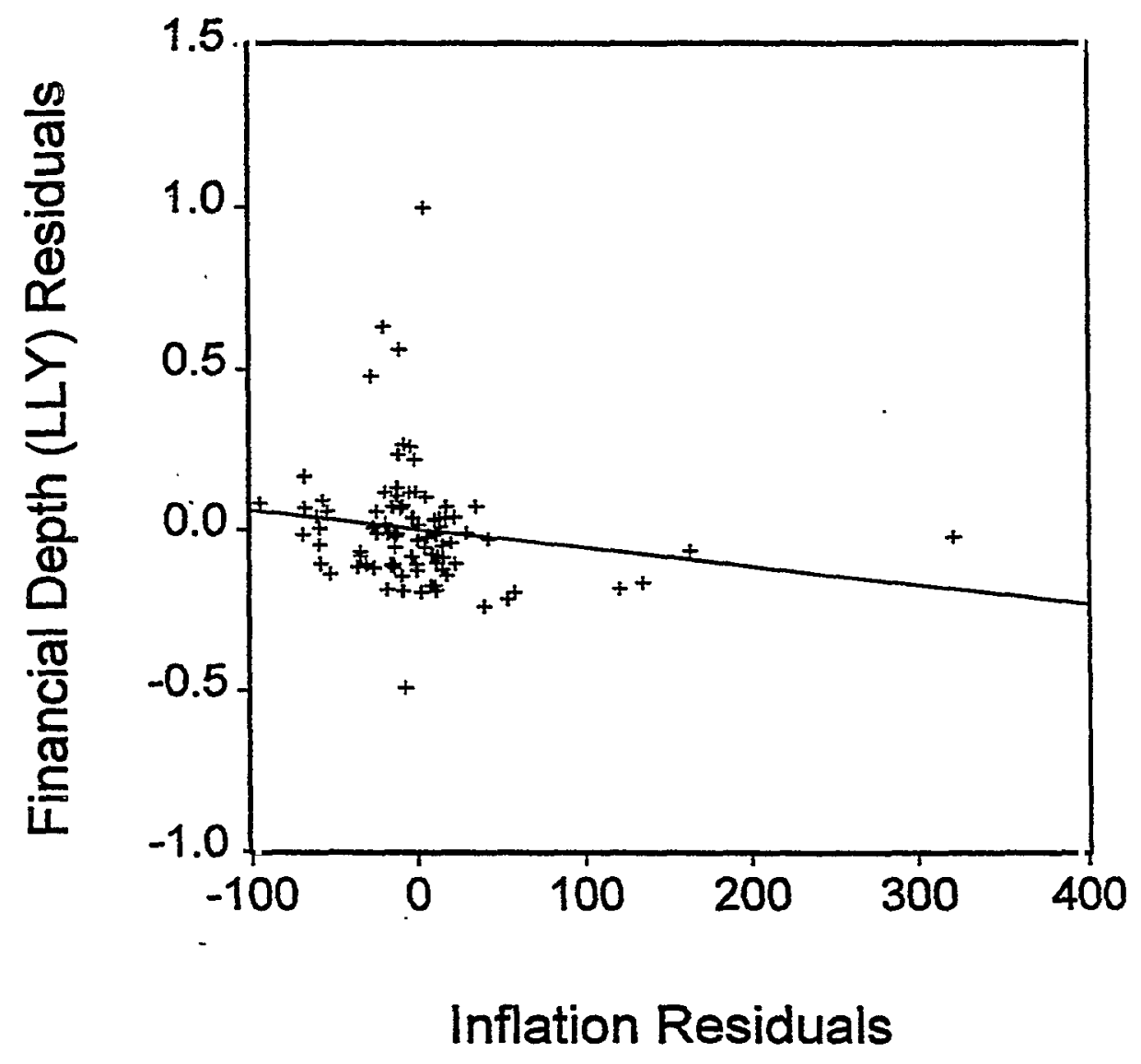


Figure 4: Partial Scatter: Financial Depth vs Inverse Inflation

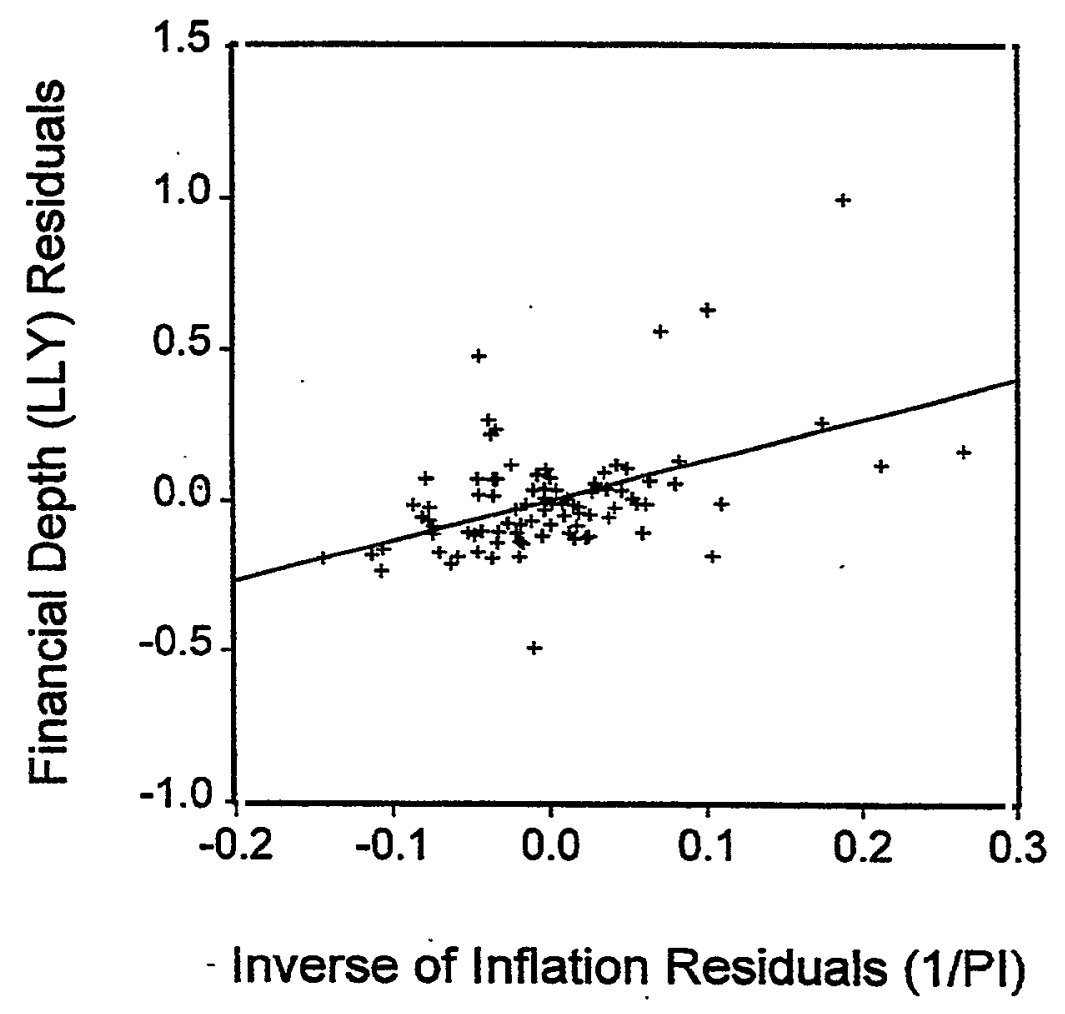


Table 1: Correlation Matrix

Banking Data Set

30 Year Average Data, 1960-1989

\begin{tabular}{|c|c|c|c|c|c|c|c|}
\hline & $\mathrm{PI}$ & STPI & BANK & PRIVY & LLY & M1Y & QLLY \\
\hline $\mathrm{PI}$ & 1.000 & $\begin{array}{c}0.967 \\
(0.000)\end{array}$ & $\begin{array}{l}-0.150 \\
(0.171)\end{array}$ & $\begin{array}{c}-0.165 \\
(0.102)\end{array}$ & $\begin{array}{l}-0.197 \\
(0.056)\end{array}$ & $\begin{array}{l}-0.172 \\
(0.097)\end{array}$ & $\begin{array}{l}-0.170 \\
(0.104)\end{array}$ \\
\hline STPI & & 1.000 & $\begin{array}{l}-0.086 \\
(0.434)\end{array}$ & $\begin{array}{c}-0.143 \\
(0.159)\end{array}$ & $\begin{array}{l}-0.159 \\
(0.125)\end{array}$ & $\begin{array}{l}-0.135 \\
(0.195)\end{array}$ & $\begin{array}{c}-0.142 \\
(0.174)\end{array}$ \\
\hline BANK & & & 1.000 & $\begin{array}{c}0.623 \\
(0.000)\end{array}$ & $\begin{array}{c}0.578 \\
(0.000)\end{array}$ & $\begin{array}{c}0.174 \\
(0.116)\end{array}$ & $\begin{array}{c}0.684 \\
(0.000)\end{array}$ \\
\hline PRIVY & & & & 1.000 & $\begin{array}{c}0.738 \\
(0.000)\end{array}$ & $\begin{array}{c}0.436 \\
(0.000)\end{array}$ & $\begin{array}{c}0.797 \\
(0.000)\end{array}$ \\
\hline LLY & & & & & 1.000 & $\begin{array}{c}0.782 \\
(0.000)\end{array}$ & $\begin{array}{c}0.945 \\
(0.000)\end{array}$ \\
\hline M1Y & & & & & & 1.000 & $\begin{array}{c}0.534 \\
(0.000)\end{array}$ \\
\hline QLLY & & & & & & & 1.000 \\
\hline
\end{tabular}

$\mathrm{P}$-values are in parentheses 
Table 2: Quartile Averages

Banking Data Set Sorted by Inflation

30 Year Average Data, 1960-1989

Means, (Medians in Parentheses)

$\begin{array}{cccccccc}\text { Quartile } & \text { PI } & \text { STPI } & \text { BANK } & \text { PRIVY } & \text { LLY } & \text { MIY } & \text { QLLY } \\ \text { ALL } & 22.088 & 49.156 & 0.709 & 0.240 & 0.369 & 0.176 & 0.197 \\ & (8.193) & (7.430) & (0.710) & (0.189) & (0.285) & (0.156) & (0.132) \\ & & & & & & & \\ 1 & 4.883 & 5.182 & 0.787 & 0.336 & 0.485 & 0.199 & 0.285 \\ & (5.089) & (4.308) & (0.816) & (0.246) & (0.382) & (0.170) & (0.238) \\ & & & & & & & \\ 2 & 7.320 & 6.366 & 0.707 & 0.239 & 0.341 & 0.190 & 0.160 \\ & (7.266) & (6.197) & (0.721) & (0.189) & (0.312) & (0.159) & (0.128) \\ 3 & 10.130 & 9.279 & 0.719 & 0.232 & 0.425 & 0.186 & 0.239 \\ & (9.789) & (8.527) & (0.714) & (0.204) & (0.408) & (0.162) & (0.232) \\ & & & & & & & \\ 4 & 69.854 & 186.210 & 0.608 & 0.148 & 0.226 & 0.130 & 0.098 \\ & (28.280) & (29.126) & (0.618) & (0.131) & (0.208) & (0.125) & (0.072) \\ & & & & & & & \\ \text { n } & 106 & 106 & 86 & 100 & 96 & 95 & 94\end{array}$


Table 3: Correlation Matrix

Stock Market Data Set

24 Year Average Data, 1970-1993

\begin{tabular}{|c|c|c|c|c|c|c|c|c|}
\hline & $\mathrm{PI}$ & MCAPGDP & TVTGDP & TOR & VOL & IAPM & ICAPM & EQRT \\
\hline $\mathrm{PI}$ & 1.000 & $\begin{array}{c}-0.094 \\
(0.518)\end{array}$ & $\begin{array}{l}-0.105 \\
(0.463)\end{array}$ & $\begin{array}{c}-0.104 \\
(0.471)\end{array}$ & $\begin{array}{c}0.843 \\
(0.000)\end{array}$ & $\begin{array}{c}0.521 \\
(0.009)\end{array}$ & $\begin{array}{c}0.766 \\
(0.000)\end{array}$ & $\begin{array}{c}0.974 \\
(0.000)\end{array}$ \\
\hline MCAPGDP & & 1.000 & $\begin{array}{c}0.313 \\
(0.027)\end{array}$ & $\begin{array}{c}0.027 \\
(0.851)\end{array}$ & $\begin{array}{l}-0.259 \\
(0.122)\end{array}$ & $\begin{array}{c}-0.355 \\
(0.089)\end{array}$ & $\begin{array}{c}-0.474 \\
(0.019)\end{array}$ & $\begin{array}{l}-0.125 \\
(0.454)\end{array}$ \\
\hline TVTGDP & & & 1.000 & $\begin{array}{c}0.832 \\
(0.000)\end{array}$ & $\begin{array}{c}0.066 \\
(0.696)\end{array}$ & $\begin{array}{l}-0.068 \\
(0.753)\end{array}$ & $\begin{array}{l}-0.187 \\
(0.381)\end{array}$ & $\begin{array}{c}-0.096 \\
(0.565)\end{array}$ \\
\hline TOR & & & & 1.000 & $\begin{array}{c}0.171 \\
(0.313)\end{array}$ & $\begin{array}{c}0.005 \\
(0.982)\end{array}$ & $\begin{array}{c}-0.076 \\
(0.723)\end{array}$ & $\begin{array}{c}0.005 \\
(0.978)\end{array}$ \\
\hline VOL & & & & & 1.000 & $\begin{array}{c}0.552 \\
(0.008)\end{array}$ & $\begin{array}{c}0.829 \\
(0.000)\end{array}$ & $\begin{array}{c}0.836 \\
(0.000)\end{array}$ \\
\hline IAPM & & & & & & 1.000 & $\begin{array}{c}0.780 \\
(0.000)\end{array}$ & $\begin{array}{c}0.511 \\
(0.013)\end{array}$ \\
\hline ICAPM & & & & & & & 1.000 & $\begin{array}{c}0.708 \\
(0.000)\end{array}$ \\
\hline EQRT & & & & & & & & 1.000 \\
\hline
\end{tabular}

P-values are in parentheses 
Table 4: Quartile Averages

Stock Market Data Set Sorted by Inflation

24 Year Average Data, 1970-1993

Means, (Medians in Parentheses)

$\begin{array}{ccccccccc}\text { Quartile } & \text { PI } & \text { MCAPGDP TVTGDP } & \text { TOR } & \text { VOL } & \text { IAPM } & \text { ICAPM } & \text { EQRT } \\ \text { ALL } & 0.383 & 0.333 & 0.109 & 0.287 & 0.068 & 4.297 & 4.078 & 0.200 \\ & (0.088) & (0.173) & (0.036) & (0.223) & (0.051) & (3.955) & (3.651) & (0.103) \\ & & & & & & & & \\ 1 & 0.050 & 0.631 & 0.269 & 0.514 & 0.050 & 3.477 & 2.874 & 0.087 \\ & (0.050) & (0.419) & (0.156) & (0.459) & (0.039) & (3.164) & (2.453) & (0.069) \\ & & & & & & & & \\ 2 & 0.078 & 0.305 & 0.095 & 0.240 & 0.044 & 2.864 & 2.497 & 0.104 \\ & (0.077) & (0.162) & (0.054) & (0.245) & (0.042) & (2.588) & (2.273) & (0.108) \\ 3 & 0.122 & 0.212 & 0.038 & 0.179 & 0.063 & 4.566 & 4.208 & 0.075 \\ & (0.119) & (0.112) & (0.026) & (0.103) & (0.069) & (4.017) & (4.510) & (0.072) \\ & & & & & & & & \\ 4 & 1.358 & 0.157 & 0.027 & 0.202 & 0.139 & 5.637 & 5.938 & 0.695 \\ & (0.385) & (0.121) & (0.014) & (0.083) & (0.105) & (5.709) & (5.405) & (0.501) \\ & & & & & & & & \\ \mathrm{n} & 51 & 50 & 51 & 50 & 37 & 24 & 24 & 38\end{array}$


Table 5: Linear Regressions

Banking Data Set

30 Year Average Data, 1960-1989

Estimated Coefficients (White's Heteroskedasticity-corrected T-statistics in Parentheses)

\begin{tabular}{|c|c|c|c|c|c|c|}
\hline \multirow{2}{*}{ Independent Variables } & \multicolumn{5}{|c|}{ Dependent Variable } & \\
\hline & BANK & PRIVY & LLY & MiY & QLLY & \\
\hline CONSTANT & $\begin{array}{c}0.665 \\
(11.064)\end{array}$ & $\begin{array}{c}0.312 \\
(4.654)\end{array}$ & $\begin{array}{c}0.538 \\
(5.748)\end{array}$ & $\begin{array}{c}0.168 \\
(4.222)\end{array}$ & $\begin{array}{c}0.344 \\
(5.101)\end{array}$ & - \\
\hline LRGDP60 & $\begin{array}{c}0.071 \\
(2.676)\end{array}$ & $\begin{array}{c}0.082 \\
(1.703)\end{array}$ & $\begin{array}{l}-0.001 \\
-(0.025)\end{array}$ & $\begin{array}{l}-0.027 \\
-(1.003)\end{array}$ & $\begin{array}{c}0.039 \\
(1.141)\end{array}$ & \\
\hline LSEC & $\begin{array}{c}0.006 \\
(0.363)\end{array}$ & $\begin{array}{c}0.022 \\
(0.979)\end{array}$ & $\begin{array}{c}0.086 \\
(3.068)\end{array}$ & $\begin{array}{c}0.028 \\
(2.027)\end{array}$ & $\begin{array}{c}0.057 \\
(3.285)\end{array}$ & \\
\hline REVC & $\begin{array}{l}-0.136 \\
-(1.509)\end{array}$ & $\begin{array}{l}-0.052 \\
-(0.889)\end{array}$ & $\begin{array}{l}-0.126 \\
-(1.727)\end{array}$ & $\begin{array}{c}0.010 \\
(0.229)\end{array}$ & $\begin{array}{l}-0.137 \\
-(2.266)\end{array}$ & \\
\hline BMP6089 & $\begin{array}{c}-0.066 \\
-(2.384)\end{array}$ & $\begin{array}{c}-0.054 \\
-(2.088)\end{array}$ & $\begin{array}{c}-0.038 \\
-(1.309)\end{array}$ & $\begin{array}{c}-0.012 \\
-(1.052)\end{array}$ & $\begin{array}{c}-0.015 \\
-(0.974)\end{array}$ & \\
\hline GOVY & $\begin{array}{c}0.649 \\
(1.902)\end{array}$ & $\begin{array}{c}0.070 \\
(0.169)\end{array}$ & $\begin{array}{c}0.566 \\
(0.954)\end{array}$ & $\begin{array}{c}0.572 \\
(1.681)\end{array}$ & $\begin{array}{c}0.161 \\
(0.482)\end{array}$ & \\
\hline $\mathrm{PI}$ & $\begin{array}{c}-0.040 \\
-(1.187)\end{array}$ & $\begin{array}{c}-0.047 \\
-(2.311)\end{array}$ & $\begin{array}{c}-0.058 \\
-(2.085)\end{array}$ & $\begin{array}{l}-0.023 \\
-(2.004)\end{array}$ & $\begin{array}{c}-0.033 \\
-(1.506)\end{array}$ & \\
\hline$\underset{n}{\operatorname{Adj} . R^{2}}$ & $\begin{array}{c}0.449 \\
80\end{array}$ & $\begin{array}{c}0.435 \\
91\end{array}$ & $\begin{array}{c}0.368 \\
88\end{array}$ & $\begin{array}{c}0.101 \\
87\end{array}$ & $\begin{array}{c}0.533 \\
86\end{array}$ & \\
\hline
\end{tabular}


Table 6: Threshold Regressions

Banking Data Set

Regressions With 30 Year Average Data, 1960-1989

Estimated Coefficients (White's Heteroskedasticity-corrected T-statistics in Parentheses)

\begin{tabular}{|c|c|c|c|c|c|}
\hline \multirow{2}{*}{ Independent Variables } & \multicolumn{5}{|c|}{ Dependent Variable } \\
\hline & BANK & PRIVY & LLY & M1Y & QLLY \\
\hline CONSTANT & $\begin{array}{r}0.739 \\
(7.574)\end{array}$ & $\begin{array}{r}0.500 \\
(4.687)\end{array}$ & $\begin{array}{l}0.793 \\
(4.324)\end{array}$ & $\begin{array}{r}0.231 \\
(2.880)\end{array}$ & $\begin{array}{r}0.535 \\
(4.463)\end{array}$ \\
\hline LRGDP60 & $\begin{array}{r}0.073 \\
(2.680)\end{array}$ & $\begin{array}{r}0.075 \\
(1.632)\end{array}$ & $\begin{array}{l}-0.011 \\
-(0.196)\end{array}$ & $\begin{array}{r}-0.028 \\
-(0.992)\end{array}$ & $\begin{array}{r}0.030 \\
(0.901)\end{array}$ \\
\hline LSEC & $\begin{array}{r}0.004 \\
(0.236)\end{array}$ & $\begin{array}{r}0.028 \\
(1.309)\end{array}$ & $\begin{array}{l}0.096 \\
(3.136)\end{array}$ & $\begin{array}{r}0.029 \\
(1.944)\end{array}$ & $\begin{array}{r}0.065 \\
(3.431)\end{array}$ \\
\hline REVC & $\begin{array}{r}-0.181 \\
-(2.123)\end{array}$ & $\begin{array}{r}-0.069 \\
-(1.257)\end{array}$ & $\begin{array}{l}-0.139 \\
-(1.951)\end{array}$ & $\begin{array}{r}0.006 \\
(0.114)\end{array}$ & $\begin{array}{r}-0.147 \\
-(2.790)\end{array}$ \\
\hline BMP6089 & $\begin{array}{r}-0.024 \\
-(0.905)\end{array}$ & $\begin{array}{r}-0.012 \\
-(0.582)\end{array}$ & $\begin{array}{l}0.022 \\
(0.961)\end{array}$ & $\begin{array}{r}0.003 \\
(0.241)\end{array}$ & $\begin{array}{r}0.028 \\
(1.673)\end{array}$ \\
\hline GOVY & $\begin{array}{r}0.512 \\
(1.607)\end{array}$ & $\begin{array}{r}-0.116 \\
-(0.289)\end{array}$ & $\begin{array}{l}0.328 \\
(0.603)\end{array}$ & $\begin{array}{r}0.500 \\
(1.477)\end{array}$ & $\begin{array}{r}-0.012 \\
-(0.040)\end{array}$ \\
\hline $\mathrm{Pl}$ & $\begin{array}{r}-0.633 \\
-(0.964)\end{array}$ & $\begin{array}{r}-1.840 \\
-(2.499)\end{array}$ & $\begin{array}{l}-2.545 \\
-(1.935)\end{array}$ & $\begin{array}{r}-0.625 \\
-(1.014)\end{array}$ & $\begin{array}{r}-1.893 \\
-(2.444)\end{array}$ \\
\hline HIPI15 & $\begin{array}{r}-0.193 \\
-(2.809)\end{array}$ & $\begin{array}{r}-0.233 \\
-(3.124)\end{array}$ & $\begin{array}{c}-0.322 \\
-(2.773)\end{array}$ & $\begin{array}{r}-0.080 \\
-(1.445)\end{array}$ & $\begin{array}{r}-0.237 \\
-(3.272)\end{array}$ \\
\hline PIHIPI15 & $\begin{array}{r}0.673 \\
(1.015)\end{array}$ & $\begin{array}{r}1.824 \\
(2.464)\end{array}$ & $\begin{array}{l}2.528 \\
(1.912)\end{array}$ & $\begin{array}{r}0.613 \\
(0.988)\end{array}$ & $\begin{array}{r}1.890 \\
(2.429)\end{array}$ \\
\hline$\underset{n}{\operatorname{Adj} .} R^{2}$ & $\begin{array}{c}0.49 \\
80\end{array}$ & $\begin{array}{l}0.50 \\
91\end{array}$ & $\begin{array}{c}0.44 \\
88\end{array}$ & $\begin{array}{c}0.11 \\
87\end{array}$ & $\begin{array}{c}0.61 \\
86\end{array}$ \\
\hline $\begin{array}{l}\text { Wald F-Statistic } \\
\text { (P-value) }\end{array}$ & $\begin{array}{c}1.718 \\
(0.194)\end{array}$ & $\begin{array}{c}1.432 \\
(0.235)\end{array}$ & $\begin{array}{c}0.798 \\
(0.374)\end{array}$ & $\begin{array}{c}1.472 \\
(0.229)\end{array}$ & $\begin{array}{c}0.040 \\
(0.842)\end{array}$ \\
\hline
\end{tabular}


Table 7: Regressions With INVPI

Banking Data Set .

Regressions With 30 Year Average Data, 1960-1989

Estimated Coefficients (White's Heteroskedasticity-corrected T-statistics in Parentheses)

\begin{tabular}{|c|c|c|c|c|c|c|}
\hline \multirow{2}{*}{\multicolumn{2}{|c|}{ Independent Variables }} & \multicolumn{5}{|c|}{ Dependent Variable } \\
\hline & & BANK & PRIVY & LLY & M1Y & QLLY \\
\hline CONSTANT & - & $\begin{array}{c}0.606 \\
(10.468)\end{array}$ & $\begin{array}{c}0.214 \\
(3.528)\end{array}$ & $\begin{array}{c}0.368 \\
(4.631)\end{array}$ & $\begin{array}{l}0.125 \\
(3.341)\end{array}$ & $\begin{array}{c}0.224 \\
(4.128)\end{array}$ \\
\hline LRGDP60 & & $\begin{array}{c}0.066 \\
(2.625)\end{array}$ & $\begin{array}{c}0.082 \\
(1.879)\end{array}$ & $\begin{array}{l}0.005 \\
(0.109)\end{array}$ & $\begin{array}{l}-0.026 \\
-(1.052)\end{array}$ & $\begin{array}{c}0.043 \\
(1.608)\end{array}$ \\
\hline LSEC & & $\begin{array}{c}0.010 \\
(0.670)\end{array}$ & $\begin{array}{c}0.021 \\
(1.051)\end{array}$ & $\begin{array}{c}0.086 \\
(3.487)\end{array}$ & $\begin{array}{l}0.027 \\
(2.089)\end{array}$ & $\begin{array}{c}0.058 \\
(3.887)\end{array}$ \\
\hline REVC & & $\begin{array}{c}-0.168 \\
-(2.297)\end{array}$ & $\begin{array}{c}-0.087 \\
-(1.967)\end{array}$ & $\begin{array}{l}-0.145 \\
-(2.774)\end{array}$ & $\begin{array}{c}-0.008 \\
-(0.227)\end{array}$ & $\begin{array}{l}-0.137 \\
-(3.376)\end{array}$ \\
\hline BMP6089 & & $\begin{array}{c}-0.039 \\
-(1.700)\end{array}$ & $\begin{array}{c}-0.015 \\
-(0.736)\end{array}$ & $\begin{array}{c}0.032 \\
(1.317)\end{array}$ & $\begin{array}{c}0.006 \\
(0.477)\end{array}$ & $\begin{array}{c}0.033 \\
(2.091)\end{array}$ \\
\hline GOVY & & $\begin{array}{c}0.545 \\
(1.734)\end{array}$ & $\begin{array}{l}-0.048 \\
-(0.124)\end{array}$ & $\begin{array}{c}0.354 \\
(0.673)\end{array}$ & $\begin{array}{c}0.508 \\
(1.525)\end{array}$ & $\begin{array}{c}0.008 \\
(0.029)\end{array}$ \\
\hline INVPI & • & $\begin{array}{c}0.006 \\
(3.251)\end{array}$ & $\begin{array}{c}0.008 \\
(3.121)\end{array}$ & $\begin{array}{c}0.014 \\
(3.074)\end{array}$ & $\begin{array}{c}0.004 \\
(1.651)\end{array}$ & $\begin{array}{c}0.010 \\
(3.964)\end{array}$ \\
\hline$\underset{n}{\operatorname{Adj} . R^{2}}$ & & $\begin{array}{c}0.496 \\
80\end{array}$ & $\begin{array}{c}0.515 \\
91\end{array}$ & $\begin{array}{c}0.500 \\
88\end{array}$ & $\begin{array}{c}0.153 \\
87\end{array}$ & $\begin{array}{c}0.665 \\
86\end{array}$ \\
\hline
\end{tabular}


Table 8: Linear Regressions

Stock Market Data Set

Regressions With 24 Year Average Data, 1970-1993

Estimated Coefficients (White's Heteroskedasticity-corrected T-statistics in Parentheses)

\begin{tabular}{|c|c|c|c|c|c|c|c|}
\hline \multirow{2}{*}{ Independent Variables } & \multicolumn{7}{|c|}{ Dependent Variable } \\
\hline & MCAPGDP & TVTGDP & TOR & VOL & IAPM & ICAPM & EQTY \\
\hline CONSTANT & 0.390 & 0.047 & -0.223 & -0.015 & 3.807 & 0.196 & 0.099 \\
\hline - & $(0.395)$ & $(0.233)$ & $-(0.586)$ & $-(0.175)$ & $(0.923)$ & $(0.059)$ & $(0.406)$ \\
\hline \multirow[t]{2}{*}{ LRGDPI70 } & 0.014 & -0.005 & 0.013 & 0.001 & -0.113 & -0.058 & 0.014 \\
\hline & $(0.276)$ & $-(0.397)$ & $(0.468)$ & $(0.281)$ & $-(0.523)$ & $-(0.336)$ & $(1.662)$ \\
\hline \multirow[t]{2}{*}{ REV } & -0.277 & -0.092 & -0.026 & 0.004 & -0.656 & 0.428 & -0.082 \\
\hline & $-(1.159)$ & $-(1.141)$ & $-(0.183)$ & $(0.279)$ & $-(0.508)$ & $(0.593)$ & $-(2.673)$ \\
\hline \multirow[t]{2}{*}{ LSEC } & 0.004 & 0.060 & 0.126 & 0.018 & 0.719 & 1.249 & -0.067 \\
\hline & $(0.025)$ & $(2.004)$ & $(1.812)$ & $(1.141)$ & $(0.827)$ & $(1.486)$ & $-(1.718)$ \\
\hline \multirow[t]{2}{*}{ BMP } & -0.004 & -0.001 & -0.002 & 0.000 & 0.006 & 0.013 & -0.002 \\
\hline & $-(1.910)$ & $-(2.211)$ & $-(1.668)$ & $(1.169)$ & $(0.369)$ & $(1.019)$ & $-(1.714)$ \\
\hline \multirow[t]{2}{*}{ GOVY } & -0.813 & -0.569 & -0.577 & -0.200 & -9.692 & -10.512 & 0.216 \\
\hline & $-(0.641)$ & $-(1.246)$ & $-(0.564)$ & $-(2.712)$ & $-(1.347)$ & $-(1.484)$ & $(0.962)$ \\
\hline \multirow[t]{2}{*}{ PI } & $=0.004$ & -0.009 & -0.015 & 0.181 & 1.565 & 3.818 & 1.329 \\
\hline & $-(0.403)$ & $-(1.939)$ & $-(1.608)$ & (5.579) & $(1.510)$ & $(2.368)$ & $(19.197)$ \\
\hline Adj. $\mathrm{R}^{2}$ & -0.027 & -0.014 & -0.028 & 0.734 & 0.040 & 0.526 & 0.955 \\
\hline$n$ & 46 & 47 & 46 & 33 & 21 & 21 & 34 \\
\hline
\end{tabular}


Table 9: Threshoid Regressions

Stock Market Data Set

Regressions With 24 Year Average Data, 1970-1993

Estimated Coefficients (White's Heteroskedasticity-corrected T-statistics in Parentheses)

\begin{tabular}{|c|c|c|c|c|c|c|c|}
\hline \multirow[b]{2}{*}{ Independent Variables } & \multicolumn{7}{|c|}{ Dependent Variable } \\
\hline & MCAPGDP & TVTGDP & TOR & VOL & IAPM & ICAPM & EQRT \\
\hline Constant & $\begin{array}{c}1.148 \\
(1.223)\end{array}$ & $\begin{array}{c}0.400 \\
(1.354)\end{array}$ & $\begin{array}{c}0.302 \\
(0.508)\end{array}$ & $\begin{array}{c}-0.002 \\
-(0.025)\end{array}$ & $\begin{array}{c}2.242 \\
(0.860)\end{array}$ & $\begin{array}{l}-1.419 \\
-(0.615)\end{array}$ & $\begin{array}{c}0.255 \\
(1.145)\end{array}$ \\
\hline LRGDP60 & $\begin{array}{c}-0.010 \\
-(0.218)\end{array}$ & $\begin{array}{c}-0.016 \\
-(0.990)\end{array}$ & $\begin{array}{l}-0.002 \\
-(0.076)\end{array}$ & $\begin{array}{c}0.001 \\
(0.194)\end{array}$ & $\begin{array}{c}-0.047 \\
-(0.273)\end{array}$ & $\begin{array}{c}0.013 \\
(0.086)\end{array}$ & $\begin{array}{c}0.010 \\
(1.330)\end{array}$ \\
\hline LSEC & $\begin{array}{c}-0.038 \\
-(0.204)\end{array}$ & $\begin{array}{c}0.041 \\
(1.311)\end{array}$ & $\begin{array}{c}0.094 \\
(1.326)\end{array}$ & $\begin{array}{c}0.018 \\
(1.223)\end{array}$ & $\begin{array}{c}0.578 \\
(0.967)\end{array}$ & $\begin{array}{c}1.075 \\
(1.344)\end{array}$ & $\begin{array}{c}-0.078 \\
-(1.981)\end{array}$ \\
\hline REVC & $\begin{array}{c}-0.063 \\
-(0.322)\end{array}$ & $\begin{array}{c}0.020 \\
(0.305)\end{array}$ & $\begin{array}{c}0.152 \\
(1.202)\end{array}$ & $\begin{array}{c}0.012 \\
(0.673)\end{array}$ & $\begin{array}{c}0.019 \\
(0.016)\end{array}$ & $\begin{array}{c}0.793 \\
(0.861)\end{array}$ & $\begin{array}{l}-0.041 \\
-(0.963)\end{array}$ \\
\hline BMP6089 & $\begin{array}{c}-0.003 \\
-(1.203)\end{array}$ & $\begin{array}{c}-0.001 \\
-(1.409)\end{array}$ & $\begin{array}{c}-0.002 \\
-(1.634)\end{array}$ & $\begin{array}{c}0.000 \\
(1.284)\end{array}$ & $\begin{array}{l}-0.004 \\
-(0.219)\end{array}$ & $\begin{array}{c}0.005 \\
(0.335)\end{array}$ & $\begin{array}{c}-0.002 \\
-(1.372)\end{array}$ \\
\hline GOVY & $\begin{array}{c}-0.631 \\
-(0.479)\end{array}$ & $\begin{array}{l}-0.490 \\
-(0.961)\end{array}$ & $\begin{array}{c}-0.441 \\
-(0.419)\end{array}$ & $\begin{array}{c}-0.197 \\
-(2.549)\end{array}$ & $\begin{array}{c}-3.783 \\
-(0.475)\end{array}$ & $\begin{array}{c}-5.832 \\
-(0.703)\end{array}$ & $\begin{array}{c}0.237 \\
(1.166)\end{array}$ \\
\hline $\mathrm{PI}$ & $\begin{array}{c}-4.557 \\
-(1.883)\end{array}$ & $\begin{array}{c}-2.352 \\
-(2.303)\end{array}$ & $\begin{array}{c}-3.381 \\
-(1.846)\end{array}$ & $\begin{array}{c}0.018 \\
(0.097)\end{array}$ & $\begin{array}{c}3.490 \\
(0.326)\end{array}$ & $\begin{array}{l}10.593 \\
(0.804)\end{array}$ & $\begin{array}{c}0.376 \\
(0.816)\end{array}$ \\
\hline HIPI15 & $\begin{array}{c}-0.564 \\
-(2.113)\end{array}$ & $\begin{array}{c}-0.274 \\
-(2.263)\end{array}$ & $\begin{array}{c}-0.295 \\
-(1.266)\end{array}$ & $\begin{array}{c}-0.012 \\
-(0.384)\end{array}$ & $\begin{array}{c}2.247 \\
(1.736)\end{array}$ & $\begin{array}{c}2.192 \\
(1.406)\end{array}$ & $\begin{array}{c}-0.114 \\
-(1.985)\end{array}$ \\
\hline PIHIPI15 & $\begin{array}{c}4.556 \\
(1.882)\end{array}$ & $\begin{array}{c}2.344 \\
(2.300)\end{array}$ & $\begin{array}{c}3.360 \\
(1.838)\end{array}$ & $\begin{array}{c}0.160 \\
(0.867)\end{array}$ & $\begin{array}{c}-3.305 \\
-(0.311)\end{array}$ & $\begin{array}{c}-7.792 \\
-(0.598)\end{array}$ & $\begin{array}{c}0.984 \\
(2.226)\end{array}$ \\
\hline$\underset{n}{\text { Adj. }} R^{2}$ & $\begin{array}{c}-0.005 \\
46\end{array}$ & $\begin{array}{c}0.036 \\
47\end{array}$ & $\begin{array}{c}-0.025 \\
46\end{array}$ & $\begin{array}{c}0.718 \\
33\end{array}$ & $\begin{array}{c}0.212 \\
21\end{array}$ & $\begin{array}{c}0.556 \\
21\end{array}$ & $\begin{array}{c}0.959 \\
34\end{array}$ \\
\hline $\begin{array}{l}\text { Wald F-statistic }{ }^{1} \\
\text { (P-value) }\end{array}$ & $\begin{array}{c}0.018 \\
(0.894)\end{array}$ & $\begin{array}{c}3.955 \\
(0.054)\end{array}$ & $\begin{array}{c}5.100 \\
(0.030)\end{array}$ & $\begin{array}{r}17.864 \\
(0.000)\end{array}$ & $\begin{array}{c}0.032 \\
(0.861)\end{array}$ & $\begin{array}{c}2.650 \\
(0.130)\end{array}$ & $\begin{array}{l}194.205 \\
(0.000)\end{array}$ \\
\hline
\end{tabular}

'Tests the null hypothesis that the coefficient on PI plus the coefficient on PIHIPI15 equals zero. 
Table 10: Regressions With INVPI and EXPPI ${ }^{1}$

Stock Market Data Set

Regressions With 24 Year Average Data, 1970-1993

Estimated Coefficients (White's Heteroskedasticity-corrected T-statistics in Parentheses)

\begin{tabular}{|c|c|c|c|c|c|c|c|}
\hline \multirow{2}{*}{ Independent Variables } & \multicolumn{7}{|c|}{ Dependent Variable } \\
\hline & MCAPGDP & TVTGDP & TOR & VOL & IAPM & ICAPM & EQTY \\
\hline CONSTANT & $\begin{array}{c}0.474 \\
(0.485)\end{array}$ & $\begin{array}{c}0.023 \\
(0.123)\end{array}$ & $\begin{array}{c}-0.213 \\
-(0.564)\end{array}$ & $\begin{array}{l}-0.086 \\
-(0.943)\end{array}$ & $\begin{array}{c}3.084 \\
(0.758)\end{array}$ & $\begin{array}{l}-1.507 \\
-(0.462)\end{array}$ & $\begin{array}{l}-0.432 \\
-(1.667)\end{array}$ \\
\hline LRGDPI70 & $\begin{array}{l}-0.009 \\
-(0.207)\end{array}$ & $\begin{array}{l}-0.011 \\
-(0.819)\end{array}$ & $\begin{array}{c}0.008 \\
(0.283)\end{array}$ & $\begin{array}{l}0.000 \\
(0.074)\end{array}$ & $\begin{array}{l}-0.113 \\
-(0.503)\end{array}$ & $\begin{array}{l}-0.062 \\
-(0.335)\end{array}$ & $\begin{array}{l}0.010 \\
(1.137)\end{array}$ \\
\hline REV & $\begin{array}{l}-0.092 \\
-(0.485)\end{array}$ & $\begin{array}{l}-0.024 \\
-(0.352)\end{array}$ & $\begin{array}{c}0.019 \\
(0.147)\end{array}$ & $\begin{array}{c}0.007 \\
(0.483)\end{array}$ & $\begin{array}{l}-0.711 \\
-(0.550)\end{array}$ & $\begin{array}{c}0.345 \\
(0.458)\end{array}$ & $\begin{array}{l}-0.061 \\
-(1.635)\end{array}$ \\
\hline LSEC & $\begin{array}{l}-0.041 \\
-(0.236)\end{array}$ & $\begin{array}{c}0.042 \\
(1.598)\end{array}$ & $\begin{array}{c}0.104 \\
(1.545)\end{array}$ & $\begin{array}{c}0.013 \\
(0.753)\end{array}$ & $\begin{array}{c}0.778 \\
(0.879)\end{array}$ & $\begin{array}{c}1.308 \\
(1.523)\end{array}$ & $\begin{array}{l}-0.103 \\
-(2.390)\end{array}$ \\
\hline BMP & $\begin{array}{l}-0.003 \\
-(1.239)\end{array}$ & $\begin{array}{l}-0.001 \\
-(1.304)\end{array}$ & $\begin{array}{l}-0.002 \\
-(1.691)\end{array}$ & $\begin{array}{l}0.000 \\
(1.104)\end{array}$ & $\begin{array}{c}0.007 \\
(0.455)\end{array}$ & $\begin{array}{c}0.015 \\
(1.138)\end{array}$ & $\begin{array}{l}-0.002 \\
-(1.944)\end{array}$ \\
\hline GOVY & $\begin{array}{l}-0.551 \\
-(0.418)\end{array}$ & $\begin{array}{l}-0.456 \\
-(0.901)\end{array}$ & $\begin{array}{l}-0.438 \\
-(0.411)\end{array}$ & $\begin{array}{l}-0.16853 \\
-(3.195)\end{array}$ & $\begin{array}{l}-10.504 \\
-(1.462)\end{array}$ & $\begin{array}{l}-11.673 \\
-(1.646)\end{array}$ & $\begin{array}{c}0.455 \\
(2.929)\end{array}$ \\
\hline INVPI & $\begin{array}{c}0.022 \\
(2.024)\end{array}$ & $\begin{array}{c}0.009 \\
(2.437)\end{array}$ & $\begin{array}{c}0.007 \\
(0.956)\end{array}$ & & & & \\
\hline EXPPI & & & & $\begin{array}{c}0.100 \\
(5.362)\end{array}$ & $\begin{array}{c}0.707 \\
(1.281)\end{array}$ & $\begin{array}{c}1.914 \\
(2.392)\end{array}$ & $\begin{array}{c}0.738 \\
(22.610)\end{array}$ \\
\hline Adj. $R^{2}$ & 0.046 & 0.058 & -0.017 & 0.720 & 0.01 & 0.48 & 0.950 \\
\hline$n$ & 46 & 47 & 46 & 33 & 21 & 21 & 34 \\
\hline
\end{tabular}

${ }^{1}$ INVPI = $1 /$ (average inflation rate); EXPPI $=\exp \{$ average inflation rate . 